\title{
Myricetin bioactive effects: moving from preclinical evidence to potential clinical applications
}

\author{
Yasaman Taheri ${ }^{1,2}$, Hafiz Ansar Rasul Suleria ${ }^{3}$, Natália Martins ${ }^{4,5}$, Oksana Sytar ${ }^{6,7}$, Ahmet Beyatlii, \\ Balakyz Yeskaliyeva ${ }^{9}$, Gulnaz Seitimova ${ }^{9}$, Bahare Salehi ${ }^{10,11^{*}}$, Prabhakar Semwal ${ }^{12,13^{*}}$, Sakshi Painuli ${ }^{12,14}$, \\ Anuj Kumar ${ }^{15}$, Elena Azzini ${ }^{16}$, Miquel Martorell ${ }^{17,18^{*}}$, William N. Setzer ${ }^{19,20}$, Alfred Maroyi $i^{21^{*}}$ and \\ Javad Sharifi-Rad ${ }^{22^{*}}$ (1)
}

\begin{abstract}
Several flavonoids have been recognized as nutraceuticals, and myricetin is a good example. Myricetin is commonly found in plants and their antimicrobial and antioxidant activities is well demonstrated. One of its beneficial biological effects is the neuroprotective activity, showing preclinical activities on Alzheimer, Parkinson, and Huntington diseases, and even in amyotrophic lateral sclerosis. Also, myricetin has revealed other biological activities, among them as antidiabetic, anticancer, immunomodulatory, cardiovascular, analgesic and antihypertensive. However, few clinical trials have been performed using myricetin as nutraceutical. Thus, this review provides new insights on myricetin preclinical pharmacological activities, and role in selected clinical trials.
\end{abstract}

Keywords: Myricetin, Antimicrobial, Antioxidant, Neuroprotection, Diabetes, Cancer, Immunomodulatory, Cardiovascular disease

\section{Introduction}

Polyphenols are a wide group of plant-derived molecules resulting from secondary metabolism, ubiquitously distributed in vegetable kingdom where they display different activities such as protective effect against UV rays, bacteria, virus and fungi infections, modulation of plant hormones, enzyme inhibition and pollinator attraction [1]. In nature, there are a

\footnotetext{
* Correspondence: bahar.salehi007@gmail.com; semwal.prabahakar@gmail.com; martorellpons@gmail.com;

amaroyi@ufh.ac.za; javad.sharifirad@gmail.com

${ }^{10}$ Noncommunicable Diseases Research Center, Bam University of Medical Sciences, Bam, Iran

${ }^{12}$ Department of Biotechnology, Graphic Era University, Dehradun, Uttarakhand 248001, India

${ }^{17}$ Department of Nutrition and Dietetics, Faculty of Pharmacy, and Centre for Healthy Living, University of Concepción, 4070386 Concepción, Chile

${ }^{21}$ Department of Botany, University of Fort Hare, Private Bag X1314, Alice 5700 , South Africa

${ }^{22}$ Zabol Medicinal Plants Research Center, Zabol University of Medical Sciences, Zabol, Iran

Full list of author information is available at the end of the article
}

plethora of different polyphenols that can be classified in the following main classes: simple phenolic acids (e.g. gallic, vanillic, syringic, $p$-hydroxybenzoic), hydroxycinnamic acid derivatives (such as caffeic acid, $p$-coumaric, ferulic, sinapic), flavonoids, stilbenes and lignans. The largest common class of polyphenols present in human diet is represented by flavonoids $[2,3]$. Chemically flavonoids are classified in flavans, flavones, flavonols, and anthocyanidins [4]. Among the flavonols, myricetin, a $3,3^{\prime}, 4^{\prime}, 5,5^{\prime}, 7$-hexahydroxyflavone, possess one of the most hydroxylated structures (Fig. 1). The solubility of myricetin in water is poor $(16.6 \mu \mathrm{g} / \mathrm{mL})$ but increases when deprotonated in basic aqueous media and in some organic solvents (dimethylformamide, dimethylacetamide, tetrahydrofuran and acetone) [5]. The chemical stability of myricetin is $\mathrm{pH}$ and temperature dependent [6]. Depending on the environment conditions, myricetin can exert, in vitro, both a potent antioxidant and a pro-oxidant effect. Buchter et al. [7] attributed its direct antioxidant action to several structural elements. On the other hand, Chobot and

(c) The Author(s). 2020 Open Access This article is licensed under a Creative Commons Attribution 4.0 International License, which permits use, sharing, adaptation, distribution and reproduction in any medium or format, as long as you give appropriate credit to the original author(s) and the source, provide a link to the Creative Commons licence, and indicate if changes were made. The images or other third party material in this article are included in the article's Creative Commons licence, unless indicated otherwise in a credit line to the material. If material is not included in the article's Creative Commons licence and your intended use is not permitted by statutory regulation or exceeds the permitted use, you will need to obtain permission directly from the copyright holder. To view a copy of this licence, visit http://creativecommons.org/licenses/by/4.0/ The Creative Commons Public Domain Dedication waiver (http://creativecommons.org/publicdomain/zero/1.0/) applies to the data made available in this article, unless otherwise stated in a credit line to the data. 


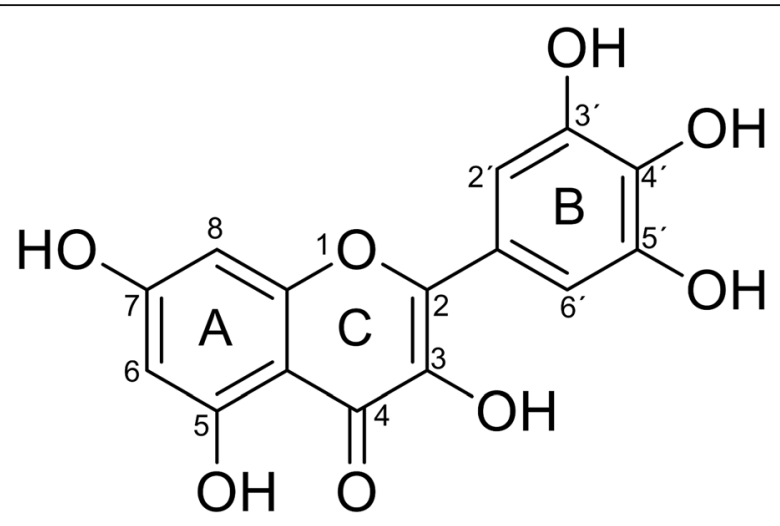

Fig. 1 Molecular structure of Myricetin

Hadacek [8] demonstrated the pro-oxidative properties of myricetin to molecular oxygen reduction to reactive oxygen species (ROS) and iron (III) to iron (II) and also highlighted the ability of myricetin to serve as a substitute for ascorbic acid, albeit less efficiently.

Myricetin is mainly present in the glycoside form (O-glycosides), in vegetables, fruits, nuts, berries, herbs, plants together with beverages, such as tea, wine, fruit and medicinal plants [9-15]. There are numerous factors that can influence myricetin levels in plant foods such as genetic and environmental factors, germination, and ripeness degree, variety, seasonal variation, and storage, processing and cooking. The estimate of total flavonoid intake is difficult to calculate, as appropriate tables of food composition are not yet available. However, reliable data on daily flavonoid intake in a population are needed to develop proper dietary recommendations and even for correct data interpretation from intervention studies. The Flemish Dietetic Association database determined an average daily intake of myricetin of $2.2 \pm 2.5 \mathrm{mg}$ Mullie et al. [16]. In a Korean adult population, Jun et al. [17] estimated an average intake of $0.8 \mathrm{mg} /$ day representing about $1-2 \%$ of flavonol subclass, while a mean intake of myricetin $2 \mathrm{mg}$ /day ranged from 1 to $4 \mathrm{mg} /$ day in adults (18 to 64 years) in the European Union was reported by Vogiatzoglou et al. [18]. The knowledge on habitual flavonoids consumption is also crucial to determine their possible impact on human health. Myricetin exhibited antioxidant properties and free radical-scavenging effects [19]. These activities seem to support a wide range of beneficial outcomes including, anti-platelet aggregation, antihypertensive, immunomodulatory, anti-inflammatory, anti-allergic, analgesic, anticancer actions and so on [6, 20-25]. The main goal of the present review is to provide new insights on myricetin preclinical pharmacological activities, and its role in selected clinical trials.

\section{Myricetin in plants}

Myricetin glycosidies include myricetin-3-O-(4" -acetyl)- $\alpha$-Larabinopyranoside, myricetin-3- $O-(3$ "-acetyl $)-\alpha-\mathrm{L}-$ arabinopyranoside, myricetin-3-O- $\beta$-D-galactopyranoside, myricetin$3-O-\alpha-L-r h a m n o p y r a n o s i d e, ~ m y r i c e t i n-3-O-\beta-D-x y l o p y r a n o-$ side, myricetin-3-O- $\alpha-\mathrm{L}-$ arabinofuranoside, myricetin-3-O(6"-galloyl)- $\beta$-D-galactopyranoside [26], myricetin-3-O- $(3 "$ $O$-galloyl)- $\alpha$-L-rhamnoside, myricetin-3-O-(2"-O-galloyl)- $\alpha$ L-rhamnoside, and myricetin-3-O- $\alpha$-L-rhamnoside [27].

The first time myricetin was identified was in plants of the Myricaceae, Comptonia peregrina (L.) Coult. and later Morella cerifera (L.) Small [28, 29]. The myricetin concentration in the plants such as Rosa canina L. (rosa hip), Urtica dioica L. (nettle), and Portulaca oleracea L. (purslane) found between 3 and $58 \mathrm{mg} / \mathrm{kg}$ [13].

Myricetin was isolated from Polygonum bellardii All. (Polygonaceae) as yellow needles $(50 \mathrm{mg})$ from aerial parts using $\mathrm{MeOH}$ extract [30]. Previously, a prescreening of leaves of 28 polygonaceous plants was estimated that myricetin glycosides were relatively rare consituents [31]. Trigonella foenum-graecum L. gemmo-modified extract had the richest content in myricetin $(830 \mathrm{mg} / \mathrm{kg})$, followed by Euphorbia tirucalli L. $(821 \mathrm{mg} / \mathrm{kg})$, rhizomes of Cyperus rotundus L. (702 mg/kg) and seed extract of T. foenum-graecum $(547 \mathrm{mg} / \mathrm{kg})$. C. rotundus gemmomodified extracts contained $104 \mathrm{mg} / \mathrm{kg}$ myricetin [10]. The highest level of myricetin content has been identified in the strawberry and spinach [9]. Species of Anacardium and Mangifera (Anacardiaceae) found to have high levels of hydroxylated compounds like myricetin, gallic acid, proanthocyanidins and flavonols. In Marantodes pumilum (Blume) Kuntze (Primulaceae) were identified quercetin, myricetin, kaempferol, catechin and epigallocatechin [32].

The most common sources of myricetin are vegetables, fruits, nuts, berries and tea [33]. Myricetin-rich foods are listed in Table 1 based on the USDA Food Database (compiled data from all fruits and vegetables that contain information on myricetin concentration) [34]. In black fruits the quantities varied between 14 and $142 \mathrm{mg} / \mathrm{kg}$ [12]. Myricetin is the most abundant flavonol of black currant, and its quantity varied significantly among black currant cultivars [35]. At the same time, honey is also a source of flavonoids, especially myricetin. The HPLC analyses of honeys from Australian Eucalyptus have shown that the flavonoids myricetin, quercetin, tricetin, kaempferol and luteolin exist in all honeys. Myricetin was found in range from $29.2-289.0 \mu \mathrm{g} / 100 \mathrm{~g}$ honey [36]. In grapes, flavonol glycosides from the following aglycons have been identified: myricetin $\left(3^{\prime}, 4^{\prime}\right.$, $5^{\prime}$-triOH), laricitrin ( $3^{\prime}-\mathrm{MeO}$ analog of myricetin) and syringetin $\left(3^{\prime}, 5^{\prime}\right.$-diMeO analog of myricetin), quercetin and kaempferol [37]. The simultaneous presence of these aglycons was detected in different types of red 
Table 1 Myricetin (mg/100 g) rich foods [34]

\begin{tabular}{ll}
\hline Cranberry & 6600 \\
Dock & 5700 \\
Sweet potato leaves & 4400 \\
Chard, swiss & 3100 \\
Broadbeans, immature seeds & 2600 \\
Rutabagas & 2100 \\
Garlic & 1600 \\
Blueberry & 1300 \\
Peppers, hot chili, green & 1200 \\
Blackberry & 700 \\
Lotus root & 600 \\
Lemon & 500 \\
\hline
\end{tabular}

Source: USDA Food Database (compiled data from all fruits and vegetables that contain information on myricetin concentration)

wine Vitis vinifera L. grapes [38], while in white wine, only quercetin, kaempferol and isorhamnetin were detected [37].

\section{Preclinical pharmacological activities of Myricetin}

Myricetin displays multiple preclinical biological effects [19]. Thus, in the following subsections, the antimicrobial, antioxidant, neuroprotective, antidiabetic, anticancer, immunomodulatory, cardioprotective, analgesic, anti-hypertensive and wound healing potential of myricetin are briefly discussed and summarized.

\section{Antimicrobial activities}

Antimicrobial mechanism of flavonoids may involve membrane disruption, inhibition of cell envelope synthesis, inhibition of nucleic acid synthesis, inhibition of bacterial virulence and quorum sensing, which impairs their ability to form biofilms, inhibition of efflux pumps, and inhibition of $\mathrm{NADH}$-cytochrome $\mathrm{C}$ reductase activity and ATP synthase [39, 40]. Myricetin inhibited Escherichia coli DNA gyrase ( $\left.\mathrm{IC}_{50} 1.18 \mathrm{mg} / \mathrm{dL}\right)$ [41], and DnaB helicase $\left(\mathrm{IC}_{50} 11.3 \mu \mathrm{M}\right)$ [42], and cellular DNA and RNA polymerases [43].

Myricetin showed a significant antimicrobial activity against foodborne pathogens in terms of minimum inhibitory concentration (MIC, mg/mL) <15.0, <15.0, < $20.0,<10.0$ at $24 \mathrm{~h}$ and $<20.0,<20.0,<15.0,<5.0$ at $60 \mathrm{~h}$ incubation for Escherichia coli, Salmonella paratyphi, Salmonella cholerasuis, and Salmonella enteritidis, respectively [44]. The compound myricetin revealed curlidependent $E$. coli biofilm formation inhibition $\left(\mathrm{IC}_{50}=\right.$ $46.2 \mu \mathrm{M}$ ), curli contributes to the robustness of $E$. coli biofilms [45].

At $100 \mu \mathrm{M}$ concentration, myricetin exhibited in vitro anti-HIV activity in cell cultures: TZM-bl (> 87\%; $\mathrm{IC}_{50}$ $20.43 \mu \mathrm{M})$, PBMC (86\%; IC $504.49 \mu \mathrm{M}, 3.23 \mu \mathrm{M})$, and $\mathrm{H} 9$ cell ( $\geq 86 \%$; $\left.\mathrm{IC}_{50} 22.91 \mu \mathrm{M}, 1.76 \mu \mathrm{M}\right)$ [46]. Myricetin exhibited the highest anti-HIV reverse transcriptase activity $\left(>49 \%, \mathrm{IC}_{50} 203.65 \mu \mathrm{M}\right)$ at the concentration of $100 \mu \mathrm{M}$ [46].

Yadav et al. [47] demonstrated the anti-tubercular activity of 15 selected flavonoids including myricetin and their structure-activity relationships were evaluated against Mycobacterium tuberculosis H37Rv strain radiometrically. Myricetin was found to be active against $M$. tuberculosis, with a MIC of $50 \mu \mathrm{g} / \mathrm{mL}$, and structure-activity relationships authenticated their anti-tubercular potential due to the presence of hydroxy groups in their structure.

The inhibitory activity of the compounds were evaluated against DNA gyrase from E. coli by DNA supercoiling. Mean antibacterial activity in terms of MIC and $\mathrm{IC}_{50}$ were $142 \mu \mathrm{g} / \mathrm{mL}$ and $1.18 \mathrm{mg} / \mathrm{mL}$ respectively. The structureactivity relationship analysis suggests that, the presence of hydroxyl and substitution in the ring $\mathrm{A}$ and $\mathrm{B}$ position are essential for the best inhibitory effects [41].

The inhibitory effect of myricetin on severe acute respiratory syndrome-coronavirus (SARS-CoV) helicase, nsP13, and hepatitis $\mathrm{C}$ virus (HCV) helicase, NS3h was also assessed [48]. Myricetin was found to inhibit SARS$\mathrm{CoV}$ helicase protein by affecting the ATPase activity $\left(\mathrm{IC}_{50} 2.71 \mu \mathrm{M}\right)$, however, it failed to affect the ATPase activity of the HCV NS3 helicase.

DeSouza and Wahidullah [49] reported the antimicrobial activity on E. coli, Klebsiella pneumoniae, Proteus mirabilis, Pseudomonas aeruginosa, Salmonella typhi, Shigella flexneri, Staphylococcus aureus, Vibrio cholerae and myricetin showed the best activity against $P$. aeruginosa (MIC $1.5 \mu \mathrm{g} / \mathrm{mL}$ ). Gendaram et al. [50] reported the myricetin antibacterial effect against $S$. aureus by the disc diffusion method $(300 \mu \mathrm{g} / \mathrm{disc}$, inhibition zone 9 $\mathrm{mm}$ ) but reported no antibacterial activities against $P$. aeruginosa, E. coli, Enterococcus faecalis, or Micrococcus luteus. However, at $100 \mu \mathrm{M}$ concentration, myricetin did not exhibit antimicrobial activity on Gram-positive bacteria but showed inhibitory activity against sortase A (SrtA) from S. aureus (92\%; $\mathrm{IC}_{50} 4.63 \mu \mathrm{M}$ ) [51]. In vitro antimicrobial activity of six natural phytochemicals including myricetin (alone and with combination) were evaluated against five strains of $P$. aeruginosa by using a time-kill assay. The compound showed the MIC as $500 \mu \mathrm{g} / \mathrm{mL}$ against all five strains of $P$. aeruginosa [52]. Other reports of the compound based on antimicrobial and antiviral studies are presented in Table 2.

\section{Antioxidant activities}

Plant-based compounds considered as natural antioxidants have attracted a large number of communities of scientist, researchers, industries and traditional healers for their health-promoting characteristics. The antioxidant 
Table 2 Antimicrobial profiling of the compound myricetin

\begin{tabular}{lll}
\hline Strains & Results & References \\
\hline Antiviral & & \\
HIV Reverse Transcriptase & $0.08^{a}$ & {$[43]$} \\
HIV Reverse Transcriptase, & $0.08^{\mathrm{b}}$ & {$[53]$} \\
Moloney murine leukemia virus & &
\end{tabular}

\section{Antimicrobial}

Gram positive

$\begin{array}{lll}\text { Actinomyces viscosus } & 20^{\mathrm{b}} & {[54]} \\ \text { Burkholderia cepacia } & >512^{\mathrm{b}} & {[55]} \\ \text { Corynebacterium diphtheriticum } & 18.2^{\mathrm{e}} & {[56]} \\ \text { Enterococcus faecalis } & 17.0^{\mathrm{e}} & {[56]} \\ \text { Enterococcus faecalis } 2400 & 17.0^{\mathrm{e}} & {[56]} \\ \text { Enterococcus faecium } & 16.8^{\mathrm{e}} & {[56]} \\ \text { Methicillin-resistant Staphylococcus aureus } & 256^{\mathrm{b}} & {[55]} \\ \text { Staphylococcus aureus ATCC6538p } & >300^{\mathrm{c}} & {[57]} \\ \text { Staphylococcus aureus } & >2000^{\mathrm{b}} & {[58]} \\ \text { Staphylococcus epidermidis ATCC14490 } & 64^{\mathrm{b}} & {[55]} \\ \text { Staphylococcus epidermidis } & >2000^{\mathrm{b}} & {[58]} \\ \text { Staphylococcus epidermidis } & 17.4^{\mathrm{e}} & {[56]} \\ \text { Staphylococcus saprophyticus } & 17.6^{\mathrm{e}} & {[56]} \\ \text { Streptococcus mutans } & 20^{\mathrm{b}} & {[54]} \\ \text { Streptococcus pneumoniae 49 } & 128^{\mathrm{b}} & {[55]} \\ \text { Streptococcus pneumoniae } & 17.4^{\mathrm{e}} & {[56]} \\ \text { Streptococcus pyogenes } & 16.4^{\mathrm{e}} & {[56]} \\ \text { Vancomycin-Resistant Enterococci (VRE) } & 512^{\mathrm{a}} & {[55]}\end{array}$

\section{Gram negative}

$\begin{array}{lll}\text { Burkholderia cepacia } & 64^{\mathrm{b}} & {[55]} \\ \text { Enterobacter aerogenes } & 256^{\mathrm{b}} & {[55]} \\ \text { Escherichia coli } & >2000^{\mathrm{b}} & {[58]} \\ \text { Escherichia coli WT } & 12.2^{\mathrm{e}} & {[56]} \\ \text { Escherichia coli BU40 } & 12.6^{\mathrm{e}} & {[56]} \\ \text { Escherichia coli FPL5014 } & 11.6^{\mathrm{e}} & {[56]} \\ \text { Escherichia coli DnaB helicase } & 11.3^{\mathrm{d}} & {[42]} \\ \text { Klebsiella pneumoniae ATCC13883 } & 64^{\mathrm{b}} & {[55]} \\ \text { Klebsiella pneumoniae } & 128^{\mathrm{b}} & {[59]} \\ \text { Klebsiella pneumoniae } & >2000^{\mathrm{b}} & {[58]} \\ \text { Klebsiella pneumoniae } & 16.6^{\mathrm{e}} & {[56]} \\ \text { Porphyromonas gingivalis } & 2500^{\mathrm{b}} & {[54]} \\ \text { Prevotella intermedia } & 1250^{\mathrm{b}} & {[54]} \\ \text { Proteus mirabilis } & 16.5^{\mathrm{e}} & {[56]} \\ \text { Pseudomonas aeruginosa ATCC27853 } & 256^{\mathrm{b}} & {[55]} \\ \text { Pseudomonas aeruginosa } & >2000^{\mathrm{b}} & {[58]} \\ \text { Pseudomonas aeruginosa PAO286 } & 15.6^{\mathrm{e}} & {[56]} \\ \text { Salmonella paratyphi A } & 14.4^{\mathrm{e}} & {[56]} \\ \text { Salmonella paratyphi B } & 14.4^{\mathrm{e}} & {[56]}\end{array}$

Table 2 Antimicrobial profiling of the compound myricetin (Continued)

\begin{tabular}{ccc}
\hline Strains & Results & References \\
\hline Salmonella typhi & $14.4^{\mathrm{e}}$ & {$[56]$} \\
Shigella dysenteriae & $15.5^{\mathrm{e}}$ & {$[56]$} \\
Shigella flexneri & $13.4^{\mathrm{e}}$ & {$[56]$} \\
Shigella sonnei & $14.6^{\mathrm{e}}$ & {$[56]$} \\
Anti-chlamydial & & \\
Chlamydia pneumoniae & $29^{\mathrm{c}}$ & {$[60]$} \\
\hline
\end{tabular}

Microbial strain is inserted when microbial type is repeated and information available

${ }^{\mathrm{a}} \mathrm{Ki}(\mu \mathrm{M})$

${ }^{\mathrm{b}}$ minimum inhibitory concentration (MIC, $\mu \mathrm{g} / \mathrm{mL}$ )

${ }^{\mathrm{c}} \mathrm{MIC}(\mu \mathrm{M})$

dhalf maximal inhibitory concentration $\left(\mathrm{IC}_{50}, \mu \mathrm{M}\right)$

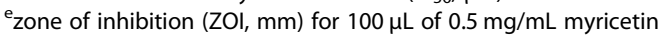

potential of myricetin has been reported by several authors in the last few decades.

Hou et al. [61] studied the antioxidant effect of HS15Myr micelles and independent myricetin by using FRAP (ferric reducing antioxidant power) and ABTS (2,2'azino-bis(3-ethylbenzothiazoline-6-sulphonic acid) assays. The ABTS assay displayed an improved value from 22.20 to $41.77 \%$ in HS15-Myr micelles and 0 to $6.12 \%$ in independent myricetin at two different concentrations and incubation periods. The FRAP assay also presented an improved value from 1.27 to $8.94 \mathrm{mM} \mathrm{Fe}^{2+} / \mathrm{g}$ in HS15-Myr micelles and 13.63 to $16.33 \mathrm{mM} \mathrm{Fe}^{2+} / \mathrm{g}$ in independent myricetin at two different concentrations and incubation periods. Myricetin in HS15-Myr micelles exhibited in both assays stronger antioxidant effects when compared to independent myricetin.

Barzegar [62] reported the ROS-protection efficiency of the compound myricetin in a cell-free and cell-based system. A low concentration of compound significantly inhibited intracellular ROS production and also protected cells against toxicity induced by peroxide compounds.

Guitard et al. [63] reported that, myricetin is more efficient than $\alpha$-tocopherol and synthetic antioxidants on preservation of omega-3 oils. Other studies on antioxidant potential of the compound are presented in Table 3.

\section{Neurobiological activities}

Natural flavonoids have exerted positive impacts on body through affecting multiple cell systems and modulating the activity of various pathways to reduce cognitive decline and neuronal dysfunction [79]. Myricetin is one of such flavonoids, and multiple studies have been conducted to assess the neuroprotective effects of this compound and its interaction with brain receptors (Table 4). The main mechanisms are shown in Fig. 2. 
Table 3 Antioxidant activities of myricetin

\begin{tabular}{|c|c|c|c|}
\hline Assay & Model & Results & Ref. \\
\hline Density functional theory & in & $\begin{array}{l}\text { The bond dissociation enthalpy computed and the compound showed ionization potentials } 161.4 \\
\mathrm{kcal} / \mathrm{mol} \text {. }\end{array}$ & [64] \\
\hline $\begin{array}{l}\text { Antioxidant response element } \\
\text { (ARE) activation }\end{array}$ & in vitro & $\begin{array}{l}\text { Activates Nrf2 antioxidant response element pathways and is involved in myricetin-induced expres- } \\
\text { sion profiling in hepatic cells. }\end{array}$ & [65] \\
\hline Deoxyribose degradation & in vitro & Significant antioxidant activity (complex with iron) in the presence of ascorbic acid. & [8] \\
\hline DPPH & in vitro & Myricetin/HP- $\beta-C D$ inclusion complex formation enhances antioxidant activity of drugs. & [66] \\
\hline DPPH & in vitro & Significant RSA dose-dependently & [50] \\
\hline DPPH, ABTS & in vitro & Inhibition activity from 13.3 to $99.8 \%$ at doses of 0.03 to $1 \mathrm{mg} / \mathrm{ml}$ during 5 to $20 \mathrm{~min}$. & [67] \\
\hline DPPH, FRAP & in vitro & High RSA in DPPH assay, and intermediate ferric reducing ability in FRAP assay. & [68] \\
\hline DPPH, FRAP, ABTS & in vitro & $\begin{array}{l}\text { Mean activity for FRAP }(27.2,26.7) \mathrm{mmol} \mathrm{Fe}^{2+} / \mathrm{L} \text {, DPPH }(7.9,9.3) \mathrm{mmol} \mathrm{TEAC} / \mathrm{L} \text {, and ABTS }(9.3,11.5) \\
\text { mmol TEAC/L. }\end{array}$ & [69] \\
\hline DPPH, FRAP, ORAC & in vitro & $\begin{array}{l}\text { EC }_{50} \text { value of DPPH, FRAP and ORAC assays were recorded as } 7.60 \mu \mathrm{g}, 8.86 \text { and } 12.99 \mathrm{mmol} \text { Trolox } \\
\text { equivalents per gram. }\end{array}$ & [70] \\
\hline DPPH, TPTZ, superoxide & in vitro & $\begin{array}{l}\text { Myricetin and its derivatives showed } \mathrm{IC}_{50} \text { value from } 1.82 \text { to } 3.27 \mu \mathrm{g} / \mathrm{mL} \text { in } \mathrm{DPPH} \text { assay and } 1.86 \text { to } \\
3.83 \mu \mathrm{g} / \mathrm{mL} \text { in superoxide assay however, } 1.38 \text { to } 2.89 \mu \mathrm{M} \text { equivalent to } \mathrm{Fe}^{2+} / \mathrm{mL} \text { for TPTZ assay. }\end{array}$ & [71] \\
\hline $\mathrm{H}_{2} \mathrm{O}_{2}$ & in vitro & Increases hydrogen peroxide resistance in Saccharomyces cerevisiae. & [72] \\
\hline $\mathrm{DPPH}, \mathrm{ROS}$ & in vitro & $\begin{array}{l}21-54 \% \text { scavenging activity in DPPH assay }(5-10 \mu \mathrm{g} / \mathrm{mL}) \text { and } 35-73 \% \text { intracellular ROS scavenging } \\
\text { activity }(1-10 \mu \mathrm{g} / \mathrm{mL}) \text {. Significantly inhibits } \mathrm{H}_{2} \mathrm{O}_{2} \text {-induced cell death and activated antioxidant } \\
\text { enzymes. }\end{array}$ & [73] \\
\hline NO & in vitro & Mean scavenging activity compared to hydrophilic antioxidants. & [74] \\
\hline ROS & in vitro & Inhibits peroxynitrite-mediated DNA damage in primary astrocytes at $5 \mu \mathrm{M}$. & [75] \\
\hline ROS & in vitro & The $I C_{30}$ value for inhibitory effect on triglyceride and ROS were recorded as $>150 \mu \mathrm{M}$ and $122.7 \mu \mathrm{M}$. & [76] \\
\hline ROS & in vitro & Inhibits $\mathrm{H}_{2} \mathrm{O}_{2}$-induced cell death and increases cell survival (65\%). & [77] \\
\hline DCFH-DA & in vivo & Inhibits ROS production in normal individuals and in patients with sickle cell anemia. & [78] \\
\hline
\end{tabular}

\section{Antidiabetic activities}

Myricetin antidiabetic activity has been reported by several authors in the last few years and limited reports are also available on its anti-obesity activity but in this review, we focused on only its antidiabetic potential. Karunakaran et al. [101] reported the in vitro effect of myricetin on high glucose-induced $\beta$-cell apoptosis, possibly via cyclin-dependent kinase 5 (CDK5) inhibition. Data revealed that myricetin $(20 \mu \mathrm{M})$ significantly protect $\beta$-cells reducing apoptosis in INS-1 cells and rat islets that were incubated with glucose at the concentration of $30 \mathrm{mM}$ for 24 and $48 \mathrm{~h}$, respectively. Docking studies predicted myricetin inhibited activation of CDK5.

The effect of myricetin was evaluated in diabetes mellitus-associated kidney injuries and dysfunction in an experimental mouse model with diabetes mellitus induced by 5 consecutive injections of low-dose streptozotocin (STZ) [20]. The data revealed that myricetin (orally twice a day, $100 \mathrm{mg} / \mathrm{kg} /$ day, for 6 moths) inhibited the $I \kappa B \alpha / N F-\kappa B$ pathway, with this pathway being independent of nuclear factor erythroid 2related factor (Nrf2) regulation. It was also reported that myricetin activates glucagon-like peptide 1 receptor (GLP-1R) and its long-term oral administration (200 mg/kg, for 40 days) validates its glucoregulatory effects [102].

Insulin's metabolic action is mediated via the activation of phosphatidylinositol 3-kinase (PI3K) and its downstream effectors, the protein kinase $\mathrm{B}$ (PKB/Akt) kinases [103]. In contrast, AMP-activated protein kinase (AMPK) signal pathway is likely to mediate the effect of insulin-independent stimuli for glucose uptake in muscle [104]. In an in vitro study, myricetin enhanced Akt and AMPK protein activity, encouraged glucose uptake and reduced insulin resistance [105]. The mechanisms of myricetin for improving insulin-sensitive tissue might be the amelioration of impaired signaling intermediates downstream of insulin receptors through enhancing the secretion of $\beta$-endorphin, which in turn led to the activation of peripheral $\mu$-opioid receptors [106, 107]. Then, myricetin affects insulin receptor phosphorylation, insulin receptor substrate-1 (IRS-1), the p85 regulatory subunit of PI3K, Akt and Akt substrate of $160 \mathrm{kD}$, with subsequent effects on glucose transporter 4 (GLUT4) translocation [108]. 
Table 4 Neurobiological effects produced by myricetin

\begin{tabular}{|c|c|}
\hline Model & Results \\
\hline \multicolumn{2}{|l|}{ Anxiety } \\
\hline $\begin{array}{l}\text { In vitro and } \\
\text { in vivo }\end{array}$ & $\begin{array}{l}\text { Dose-dependent reduction in lithium-induced head twitches and anxiolytic activity by altering 5-hydroxytryptamine } \\
\text { transmission. }\end{array}$ \\
\hline \multicolumn{2}{|c|}{ Alzheimer disease } \\
\hline In vitro & Pro-oxidant agent and reduced the formation of ordered amyloid beta (Aß)42 aggregation. \\
\hline In silico & Destabilizes the $\beta$-sheet ordered amyloid oligomers formed by the undecapeptide A $\beta$ (25-35) model. \\
\hline In vitro & $\begin{array}{l}\text { Marked modulation of metal-induced } A \beta \text { aggregation, more than metal-free } A \beta \text { aggregation. Increase cell survival rate of } \\
A \beta \text { (with metal ions). }\end{array}$ \\
\hline In vitro & $\begin{array}{l}\text { Increases a-secretase (ADAM10) enzyme activity and decreases of } \beta \text {-secretase (BACE-1). It also exerts neuroprotective activ } \\
\text { ity against } A \beta(1-42) \text { with multifunctional role in counteracting } A D \text { progress. }\end{array}$ \\
\hline In vitro & Dose-dependent inhibition of a-synuclein fibrils formation and destabilization ( $\left.E C_{50}=0.21-1.8 \mu \mathrm{M}\right)$. \\
\hline In vitro & $\begin{array}{l}\text { Dose-dependent inhibition of } A \beta \text { fibrils formation from fresh } A \beta(1-40) \text { and } A \beta \text { (1-42). The } E C_{50} \text { value for formation, } \\
\text { extension and destabilization } A \beta \text { fibrils ranges from } 0.13-1.8 \mu \mathrm{M} \text {. }\end{array}$ \\
\hline In vivo & $\begin{array}{l}\text { Increases the number of hippocampal CA3 pyramidal neurons and survival in a rat model }(10 \mathrm{mg} / \mathrm{kg}) \text {. Improved learning } \\
\text { and memory in a rat model with AD. }\end{array}$ \\
\hline
\end{tabular}

CNS
In vitro Reduces the aggregation of different abnormal proteins and eliminates various toxic proteins related to neurodegenerative diseases. Improves physiological functions of Hsp70 molecular chaperone and reduces mis-folded proteins. Increases GABA receptor activity via calcium channel/ CaMK-II dependent mechanism, which is distinctively different from
In vitro and in vivo that of most existing benzodiazepine binding site agonists of GABA receptor.
In vivo Increases mRNA for brain-derived neurotrophic factor (BDNF) in the hippocampus of male C57BL/6 mice at 10 and $20 \mathrm{mg} /$ $\mathrm{kg}$ (7 days).
In vivo Increases BDNF concentrations in the hippocampus of male C57BL/6 mice at $50 \mathrm{mg} / \mathrm{kg}$ (21 days).
In vivo
Enhances expression and activity of ERK1/2-CREB pathway and $\mathrm{Na}^{+}, \mathrm{K}^{+}$-ATPase while reduces oxidative stress level in hippocampus. Improves learning and memory when compared with D-galactose.

\section{Epilepsy}

In vivo Reduces seizure severity and mortality rates in mouse models and signaling pathways (BDNF-TrkB) and regulates GAD65/ GABA with MMP-9 expression.

\section{Huntington disease}

In vivo Interacts with RNA, especially CAG motif, and decreases the huntingtin protein translation and sequestration. Reduces cytotoxicity in $\mathrm{HD}$ and other polyQ disease models.

\section{Parkinson disease}

\begin{tabular}{|c|c|c|}
\hline In vitro & $\begin{array}{l}\text { Suppresses intracellular ROS production, re-establishes mitochondrial trans-membrane potential, and inhibits MKK4 and JNK } \\
\text { activation. }\end{array}$ & [95] \\
\hline $\begin{array}{l}\text { In vitro and } \\
\text { in vivo }\end{array}$ & $\begin{array}{l}\text { Inhibits activation of microglia (neuroinflammation), expression of pro-inflammatory mediators and reduces the number of } \\
\text { dopaminergic neurons. }\end{array}$ & [96] \\
\hline In vivo & Dose-dependent delay in climbing ability loss, but increases the life span of flies expressing human a-synuclein in brain. & [97] \\
\hline In vivo & Prevents the loss of dopaminergic neurons and dopamine content in brain of Parkinson flies. & [98] \\
\hline In vivo & Dose-dependent inhibitory activity on a-synuclein aggregation. & [99] \\
\hline In vivo & $\begin{array}{l}\text { Diminishes dopamine neuron degeneration, which is induced by 6-hydroxydopamine and 1-methyl-4-phenyl-pyridinium in } \\
\text { substantia nigra-striatum. }\end{array}$ & \\
\hline
\end{tabular}

$\mathrm{A} \beta$ amyloid beta, CNS central nervous system, BDNF brain-derived neurotrophic factor

Other previous studies on antidiabetic potential of the compound are shown in Table 5.

\section{Anticancer activities}

Cancer is responsible for second highest cause of death across the globe [124, 125]. It has been reported that number of death due to this devastating disease would expand to over 13 million by 2030 [126, 127]. Laboratory and clinical studies have reported that myricetin from natural sources exerts promising effects against various types of cancer $[19,21]$. The dietary compound myricetin also has the potential to inhibit key enzymes involved in cancer initiation and growth.

Myricetin has presented cytotoxic activity in human colon cancer cells. Kim et al. [21] demonstrated that myricetin significantly induces the $\mathrm{Bcl} 2$-associated $\mathrm{X}$ 


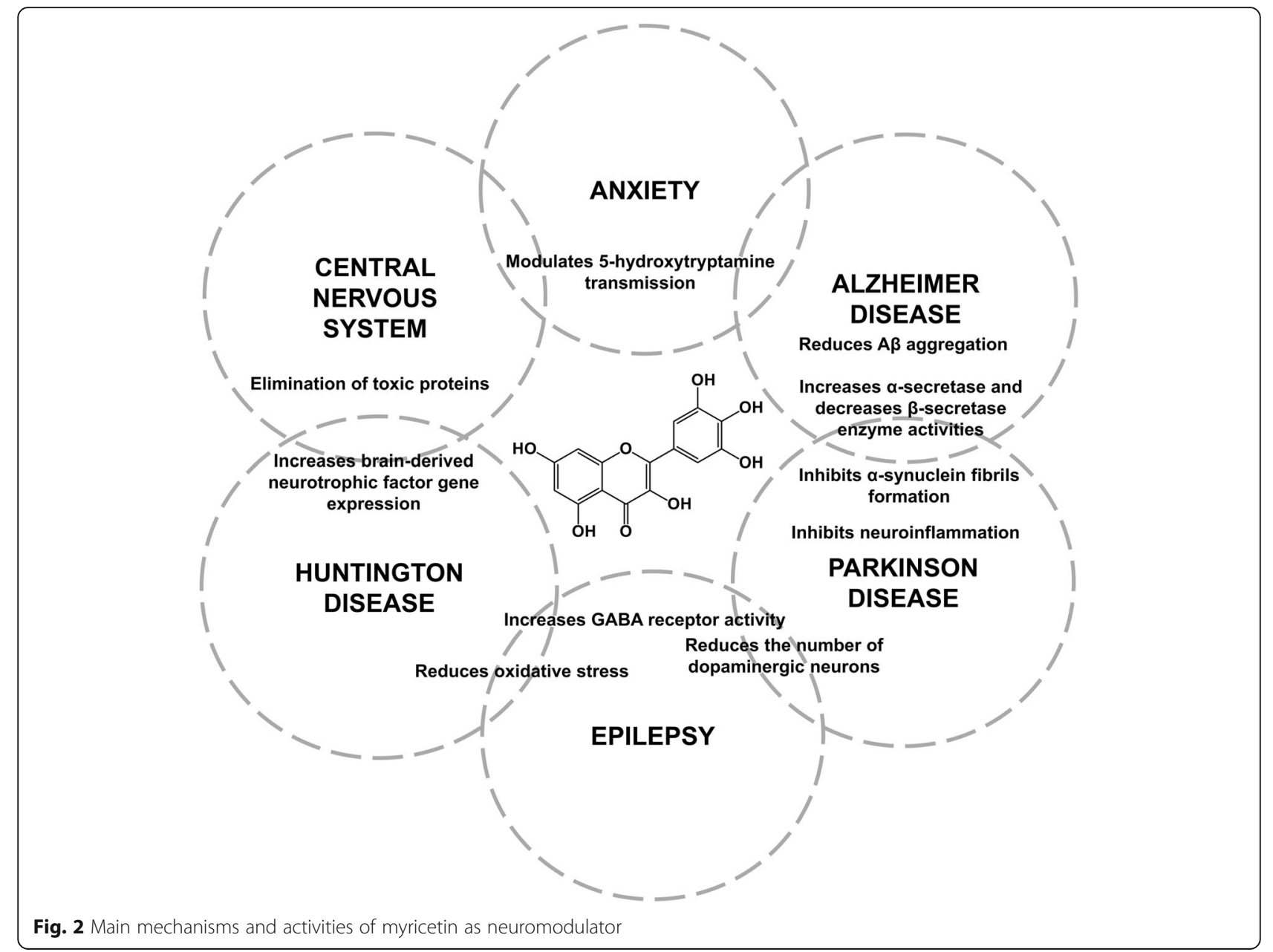

protein $(\mathrm{BAX}) / \mathrm{Bcl} 2$ ratio, and induces apoptosis of HCT-15, in a dose-dependent manner (5 to $100 \mu \mathrm{M}$ ). This study suggested that myricetin can be utilized for the design of therapeutic agents against human colon cancer. Myricetin also acts as a potent inhibitor of human flap endonuclease 1 (hFEN1) protein (IC 50690 $\mathrm{nM}$ ), based on inhibitory mechanisms, molecular docking, and cancer cell-based assays [128]. The hFEN1 protein is a functional member of the $5^{\prime}$-nuclease superfamily. By chemical nature, hFEN1 is a metal iondependent and structure-specific nuclease and also instrumental in DNA replication and repairing processes. Molecular docking studies revealed that ring A of myricetin compound, including 4-keto and 5-OH, was found stretched towards the two divalent metal ions. Both metal ions are critical as they seem to interact with Arg100 and Lys93 amino acids through hydrogen bonds. These interacted residues are well known for their critical interplay in hFEN1's activity during human colon cancer.

Myricetin has also been shown to protect against ovarian cancer through suppressing ovarian cancer cell angiogenesis [129]. Anti-angiogenic effects of myricetin (5 to $20 \mu \mathrm{M}$ ) assessed through in vitro (HUVEC) and in vivo (CAM) models revealed that this compound significantly inhibits angiogenesis induced by OVCAR-3 cells. In SKOV3 human ovarian cancer cells, myricetin inhibited viability and induced apoptosis $(40 \mu \mathrm{g} / \mathrm{mL}$, time-dependent manner) through endoplasmic reticulum stress and DNA double-strand breaks [130]. Zheng et al. [131] stated that in A2780 and OVCAR3 ovarian cancer cells, the dietary flavonoid myricetin induced significant cytotoxicity $\left(\mathrm{IC}_{50}=25 \mu \mathrm{M}\right)$. In a recent study, Tavsan and Kayali [132] reported that myricetin suppressed ovarian cancer cell growth, induced apoptosis, arrested cell cycle and also had the potential to inhibit cell invasion in a significant manner $\left(\mathrm{IC}_{50}=184 \mu \mathrm{M}\right.$ A2780, $32 \mu \mathrm{M}$ OVCAR-3, $3.3 \mu \mathrm{M}$ SKOV3, and $>500 \mu \mathrm{M}$ OSF). Thus, it can be concluded that myricetin has enough potential to cope with ovarian cancer in a significant manner.

Myricetin has potent anticancer-promoting activity against skin cancer. It was found capable of inhibiting neoplastic cell transformation and mitogen-activated 
Table 5 Previous studies on preclinical antidiabetic potential of myricetin

\begin{tabular}{|c|c|c|c|}
\hline Compound / Plant species & Model & Results & Ref. \\
\hline Myricetin & in vivo & $\begin{array}{l}\text { Enhanced enzymatic and non-enzymatic antioxidant defense system and showed protective } \\
\text { effects against oxidative damage in liver and kidney of streptozotocin-cadmium-induced dia- } \\
\text { betic model. }\end{array}$ & [109] \\
\hline Myricetin & in vivo & Inhibitory activity against a-glucosidase $\left(\mathrm{IC}_{50}=414 \mu \mathrm{M}\right)$ in dose dependent manner. & [110] \\
\hline Myricetin & in vivo & Anti-hyperglycemic and renoprotective effects at $1.0 \mathrm{mg} / \mathrm{kg}$. & [111] \\
\hline Myricetin & in vivo & $\begin{array}{l}\text { Improved and re-established renal functions and activities of the glutathione peroxidase and } \\
\text { xanthine oxidase enzymes in diabetic rat model. }\end{array}$ & [112] \\
\hline Myricetin & in vivo & Antidiabetic activity against t-BHP-induced oxidative stress. & [113] \\
\hline Myricetin & in vivo & Reduced glycemia in diabetic rats up to $50 \%$ after 2 days of treatment at $3 \mathrm{mg} / 12 \mathrm{~h}$. & [114] \\
\hline Myricetin & in vivo & $\begin{array}{l}\text { Stimulated lipogenesis in rat adipocytes and enhanced the stimulatory effect of insulin }\left(E C_{50}=\right. \\
65 \mu \mathrm{M}) \text {. }\end{array}$ & [115] \\
\hline Myricetin & in vitro & $\begin{array}{l}\text { Inhibited intestinal a-glucosidase (29\%) and porcine a-amylase (64\%) with } I_{50} \text { vale of } 0.38 \\
\text { mM. }\end{array}$ & [116] \\
\hline $\begin{array}{l}\text { Abelmoschus moschatus Medik. (aerial } \\
\text { part) }\end{array}$ & in vivo & Improved insulin sensitivity in rats. & [117] \\
\hline $\begin{array}{l}\text { Ampelopsis grossedentata (Hand.- } \\
\text { Mazz.) W.T. Wang (leaves) }\end{array}$ & in vivo & Inhibitory activity against a-glucosidase $\left(I_{50}=319.3 \mu \mathrm{M}\right)$. & [118] \\
\hline Azadirachta indica A.Juss. (leaves) & in vivo & Enhanced insulin signaling pathway and glucose utilization in skeletal muscle. & [119] \\
\hline Hovenia dulcis Thunb. (seeds) & in vitro & Inhibited intestinal a-glucosidase with $\mathrm{IC}_{50}=3 \mu \mathrm{g} / \mathrm{mL}$ and a-amylase with $\mathrm{IC}_{50}=662 \mu \mathrm{g} / \mathrm{mL}$. & [120] \\
\hline Myrtus communis L. (leaves) & in vivo & Significant antidiabetic activity in diabetic models. & [121] \\
\hline Syzygium cumini (L.) Skeels (seeds) & in vitro & Inhibitory activity against a-glucosidase $\left(I C_{50}=1.7 \mu \mathrm{g} / \mathrm{mL}\right)$ and a-amylase $\left({ }^{\prime} C_{50}=7.62 \mu \mathrm{g} / \mathrm{mL}\right)$. & [122] \\
\hline $\begin{array}{l}\text { Syzygium malaccense (L.) Merr. \& } \\
\text { L.M.Perry (leaves) }\end{array}$ & in vitro & $\begin{array}{l}\text { Inhibitory activity against a-glucosidase }\left({ }^{\prime} C_{50}=15.52 \mu \mathrm{g} / \mathrm{mL}\right) \text { and a-amylase }\left(I C_{50}=147.30 \mu \mathrm{g} /\right. \\
\mathrm{mL}) \text {. }\end{array}$ & [123] \\
\hline
\end{tabular}

protein kinase 1 (MEK1) activity (myricetin 1 or $5 \mu \mathrm{M}$ ) [133]. Molecular interaction between myricetin and MEK1 suppressed MEK1 activity leading to downstream signaling to the ERK/p90RSK/AP-1 pathway. In another study, myricetin has been presented as a potent chemoprotective agent against skin cancer [134]. Myricetin can bind directly to central kinases including PI3-K, Akt, JAK1, Raf1, MEK1, MKK4, and Fyn, which regulate multiple cell signaling pathways in cancer cells. Myricetin inhibited 12-O-tetradecanoylphorbol-13-acetate (TPA)and epidermal growth factor (EGF)-induced cell transformation by 76 and $72 \%$, respectively at $10 \mu \mathrm{M}$ concentration. Sun et al. [135] recently reported that myricetin has anticancer activity against skin cancer A431 cell lines, by inducing apoptosis and cell cycle arrest and exhibited low toxicity.

An earlier in vitro study demonstrated the antimetastatic effect of myricetin in human lung adenocarcinoma A549 cells [136]. This study revealed that myricetin ( 5 to $20 \mu \mathrm{M}$ ) suppresses adenocarcinoma A549 cell invasion and migration through inhibition of the ERK pathway in a time-dependent manner. Along with a combination of radiotherapy, myricetin was found responsible to enhance the tumor radio-sensitivity of lung cancer A549 and H1299 cells through significant suppression of cell-surviving fraction and proliferation [137]. Wang et al. [138] found that the combination of myricetin with 5-fluorouracil chemotherapy has the potential to enhance tumor chemo-sensitivity of esophageal cancer EC9706 cells. Sun et al. [139] investigated the function of myricetin phytochemical against human T24 bladder cancer in a dose- and time-dependent fashion, and stated that myricetin significantly inhibits both T24 cancer cells viability and proliferation $\left(\mathrm{IC}_{50}=85 \mu \mathrm{M}\right)$.

\section{Immunomodulatory activities}

The preclinical immunomodulatory effects of myricetin have also been increasingly reported. Ghassemi-Rad et al. [140] concluded that myricetin has the potential to inhibit T-lymphocyte activation in a mouse model through bead-immobilized anti-CD3 and anti-CD28 monoclonal antibodies. This study clarified the mechanism of action and reported the suppressive effect of myricetin on $\mathrm{T}$ lymphocytes mediated through extracellular $\mathrm{H}_{2} \mathrm{O}_{2}$ generation. In mouse primary macrophages and RAW264.7 monocytic cell-line, this phenolic compound was found to inhibit the lipopolysaccharide (LPS)-induced interleukin (IL)-12 production in a significant manner through down-regulation of NF- $\mathrm{kB}$ binding activity [22]. In isolated rat aortic rings, myricetin induced endothelium-dependent contractile responses at $50 \mu \mathrm{M}$. Earlier, Jiménez et al. [141] reported that, in cultured bovine endothelial cells, this compound is responsible for stimulating the production of cytosolic free calcium. In a 
dose-dependent manner, myricetin inhibited the secretion of a potent $\mathrm{T}$ cell growth factor, namely IL-2 protein from mouse EL-4 T cells, activated with phorbol 12myristate 13-acetate (PMA) plus ionomycin [142]. In vitro evidence demonstrated that at 5-100 $\mu \mathrm{M}$, myricetin inhibits CD69 expression and lymphocytes proliferation in a mouse model. Moreover, an in vitro investigation revealed that myricetin significantly effects IL-2 expression. However, further in vitro and in vivo investigations are required to explore myricetin as an immunomodulatory agent.

\section{Cardioprotective activity}

Previous studies have demonstrated that myricetin also has beneficial effects on the human vascular system [23]. In human umbilical vein endothelial cells, myricetin $(100 \mu \mathrm{M})$, revealed vasculoprotective effects through changes at the transcriptional level [143]. Myricetin has been presented as a functional agent towards preventing atherosclerosis through inhibition of CD36 cell surface protein and mRNA expression in a significant manner [144]. In isolated and Langendorff-perfused rat hearts, without affecting contractility and relaxation, myricetin elicited coronary dilation [145]. In Triton-treated hyperlipidemic rats, evidence from an in vivo investigation demonstrated that myricetin exerts lipid-lowering activity and suggests that myricetin can be utilized in the treatment of hyperlipidemia and cardiovascular diseases (CVD) [146].

In Wistar rats, myricetin significantly inhibited the effects of histopathological changes of isoproterenol on heart rate, the levels of different cardiac marker enzymes, including lactate dehydrogenase (LDH), creatine kinase (CK), aspartate aminotransferase (AST), superoxide dismutase (SOD) and catalase (CAT), as well changes in vascular reactivity and electrocardiographic patterns [147].

A mechanism-based study by Scarabelli et al. [148] demonstrated that myricetin exerts strong inhibitory activity against signal transducer and activator of transcription 1 (STAT1) activation, and also protects the heart from ischemia/reperfusion-injury. The available genomic and genetics data from preclinical experiments have shown that myricetin is likely to confer the first line of defense against cardiovascular and other associated diseases.

\section{Analgesic activities}

In acetic acid-induced writhing response, formalininduced paw licking, sedative activity and hot plate test models, myricetin revealed potent analgesic effects, closely related with peripheral analgesia, but not with the opioid system [24]. The compound also produced a significant analgesic effects in a rat model of neuropathic pain, by decreasing spinal nerve ligation-induced mechanical allodynia and thermal hyperalgesia lasting for several hours (0.1-10 mg/kg i.p.) [149].

\section{Antihypertensive activities}

The antihypertensive effects of myricetin were evaluated in the deoxycorticosterone acetate (DOCA)-salt-hypertensive rat model. Myricetin reduced systolic blood pressure, vascular reactivity changes and reversed the increased heart rate induced by DOCA. At oral doses of 100 and $300 \mathrm{mg}$ myricetin $/ \mathrm{kg}$ b.w., the compound displayed antihypertensive propertie in the DOCA rat model of hypertension [25]. In another study, the compound lowered the high blood pressure that was induced by fructose doses of 100 and $300 \mathrm{mg} / \mathrm{kg}$ p.o. in rats and reversed sugar-triggered metabolic changes [150].

\section{Wound healing}

The wound-healing effects of myricetin-3-O- $\beta$-rhamnoside were investigated on three different types of cells, keratinocytes, fibroblasts, and endothelial cells. The compound exhibited significant wound healing activity at $10 \mu \mathrm{g} / \mathrm{mL}$ [151].

\section{Myricetin in clinical trials}

Although the number of clinical studies reporting myricetin health benefits in ailments and disorders is low, the increasing data from preclinical studies have supported its beneficial effects [152, 153].

In a 4-week randomized placebo-controlled clinical trial the effect of $300 \mathrm{mg}$ Blueberin $(250 \mathrm{mg}$ Blueberry leaves, Vaccinium arctostaphylos L., and $50 \mathrm{mg}$ myricetin, three times per day) on fasting plasma glucose and some other biochemical parameters has been investigated in 42 female volunteers ( $46 \pm 15$ years; body mass index, BMI, $25 \pm 3 \mathrm{~kg} / \mathrm{m}^{2}$ ) with diabetes type 2 . The Blueberin treatment significantly reduced fasting plasma glucose from $143 \pm 5.2 \mathrm{mg} / \mathrm{L}$ to $104 \pm 5.7 \mathrm{mg} / \mathrm{L}$. In addition to antidiabetic effects, results showed that Blueberin also possessed pharmacologically relevant antiinflammatory properties, reduced plasma enzyme levels of alanine aminotransferases (ALT), AST, glutamyltransferase (GGT), and reduced serum C-reactive proteins (CRP) [154]. Emulin ${ }^{\mathrm{Tm}}$ (250 $\mathrm{mg}$ of patented blend of chlorogenic acid, myricetin, and quercetin), when regularly consumed, was able not only to lower the acute glycemic impact of foods, but also to chronically decrease blood glucose levels in type 2 diabetic humans (reductions between 1 and 5\%) [155]. This study was performed in 40 male and female with fasting glucose range between 126 to $249 \mathrm{mg} / \mathrm{mL}$ and a BMI $\geq 30 \mathrm{~kg} / \mathrm{m}^{2}$.

Data from different studies also indicate the importance of myricetin as a chemopreventive agent, acting on cell proliferation, signaling mechanisms, apoptosis, 
angiogenesis, and tumor metastasis [156]. Through the analysis of habitual food consumption of 10,054 participants of Finnish Mobile Clinic Health Examination Survey developed during 1966-1972, Knekt et al. [157] estimated that higher myricetin intakes in men led to lower prostate cancer risk. In a prospective study, Gates et al. [158] analyzed the association between the 5 common dietary flavonoids (myricetin, kaempferol, quercetin, luteolin and apigenin) intake and epithelial ovarian cancer incidence in 66,940 women. No clear association was found between total intake of examined flavonoids and incidence of ovarian cancer (Relative Risk $[R R]=$ 0.75 for the highest versus lowest quintile, $95 \%$ confidence interval $[\mathrm{CI}]=0.51-1.09$; $\mathrm{p}$-trend $=0.02$ ), nor for myricetin intake $(R R=0.72,95 \% C I=0.50-1.04$; $p$ trend $=0.01$ ). However, there was a significant 40 and $34 \%$ decrease in ovarian cancer incidence for the highest versus lowest quintile for kaempferol and luteolin intake, respectively [158]. The association between flavonoids and flavonoid-rich foods intake and exocrine pancreatic cancer development within the $\alpha$-tocopherol, $\beta$-carotene cancer prevention study cohort were also examined [159]. Of the 27,111 male smokers with 306 pancreatic cancers, the data obtained suggests that a flavonoid-rich diet may decrease pancreatic cancer risk in male smokers not consuming supplemental $\alpha$-tocopherol and/ or $\beta$-carotene. Tang et al. [160] showed that high/increased flavonoids (e.g., myricetin) intake is associated with lower lung cancer risk in their studied population (meta-analysis of 8 prospective studies and 4 casecontrol studies involving 5073 lung cancer cases and 237,981 non-cases).

The intake of $36 \mathrm{~g}$ lyophilized grape powder (rich in flavans, anthocyanins, quercetin, myricetin, kaempferol, and resveratrol) also had a great impact in key risk factors for coronary heart disease (lowered levels of triglyceride, lowdensity lipoproteins, apolipoproteins B and E) in both preand post-menopausal women [161]. The study was performed on 24 pre- and 20 post-menopausal women for 4 weeks. However, wide ranges of clinical studies are still needed on the potential activities of myricetin which have been already indicated through in vitro and in vivo experiments.

\section{Conclusions}

Myricetin is a flavonoid present in many foods that has shown biological activities in numerous studies and has a potential use as a nutraceutical. Its antimicrobial and antioxidant role is widely studied, and numerous studies have shown neurobiological activities and a potential beneficial impact on AD, PD, HD and ALS. Also, preclinical studies have revealed antidiabetic, anticancer, immunomodulatory, anti-cardiovascular, analgesic and antihypertensive activities. These studies investigated the effect of myricetin, pure compound or plant extract rich in this compound. In plant studies, the extracts rich in myricetin always have other flavonoids that have also shown antioxidant activity alone. Nevertheless, new well-designed studies have to be performed to study all of the biological effects described before, as well as preclinical studies comparing the effect of myricetin compared to other flavonoids and phytochemicals. In the case of neurological diseases, more in-depth studies have to be designed to show the pre-clinical results.

\section{Abbreviations}

ABTS: 2,2'-azino-bis(3-ethylbenzothiazoline-6-sulphonic acid; ALT: Alanine aminotransferases (ALT); AMPK: AMP activated protein kinase; AST: Aspartate aminotransferase; BAX: BCI2-associated X protein; CAT: Catalase; CDK5: Cyclindependent kinase 5; Cl: Confidence interval; CK: Creatine kinase; CRP: Creactive proteins; CVD: Cardiovascular disease; DOCA: Deoxycorticosterone acetate; EGF: Epidermal growth factor; FRAP: Ferric reducing antioxidant power; GGT: Glutamyltransferase; GLUT4: Glucose transporter 4; GLP-

1R: Glucagon-like peptide 1 receptor; HCV: Hepatitis C virus; hFEN1: Human flap endonuclease 1; IL: Interleukin; IRS-1: Insulin receptor substrate-1;

LDH: Lactate dehydrogenase; LPS: Lipopolysaccharide; MEK1: Mitogenactivated protein kinase 1; MIC: Minimum inhibitory concentration; Nrf2: Nuclear factor erythroid 2-related factor; PI3K: Phosphatidylinositol 3kinase; PKB: Protein kinase B; PMA: Phorbol 12-myristate 13-acetate; ROS: Reactive oxygen species; SARS-CoV: Severe acute respiratory syndromecoronavirus; SOD: Superoxide dismutase; SrtA: Sortase A; STAT1: Signal transducer and activator of transcription 1; STZ: Streptozotocin; TPA: 12-Otetradecanoylphorbol-13-acetate; RR: Relative risk

\section{Acknowledgments}

This work was partially supported by CONICYT PIA/APOYO CCTE AFB170007. N. Martins would like to thank the Portuguese Foundation for Science and Technology (FCT-Portugal) for the Strategic project ref. UID/BIM/04293/2013 and "NORTE2020 - Northern Regional Operational Program" (NORTE-01-0145FEDER-000012).

\section{Authors' contributions}

All authors (YT, NM, OS, AB, BY, GS, BS, PS, SP, AK, EA, MM, AM, JS-R) contributed to the manuscript. Conceptualization, BS and JS-R; validation investigation, resources, data curation, writing - all authors; review and editing, NM, PS, AM, MM, BS, JS-R and HARS All the authors read and approved the final manuscript.

\section{Funding}

This research received no external funding.

\section{Availability of data and materials}

Not applicable.

Ethics approval and consent to participate

Not applicable.

Consent for publication

All the authors read and approved the final manuscript.

\section{Competing interests}

The authors declare no conflict of interest.

\section{Author details}

${ }^{1}$ Phytochemistry Research Center, Shahid Beheshti University of Medical Sciences, Tehran, Iran. ${ }^{2}$ Department of Pharmacology and Toxicology, School of Pharmacy, Shahid Beheshti University of Medical Sciences, Tehran, Iran.

${ }^{3}$ Department of Agriculture and Food Systems, The University of Melbourne, Melbourne, Australia. ${ }^{4}$ Faculty of Medicine, University of Porto, Alameda Prof. Hernâni Monteiro, 4200-319 Porto, Portugal. ${ }^{5}$ Institute for Research and Innovation in Health (i3S), University of Porto, 4200-135 Porto, Portugal. ${ }^{6}$ Department of Plant Biology Department, Taras Shevchenko National 
University of Kyiv, Institute of Biology, Volodymyrska str., 64, Kyiv 01033, Ukraine. 'Department of Plant Physiology, Slovak University of Agriculture, Nitra, A. Hlinku 2, 94976 Nitra, Slovak Republic. ${ }^{8}$ Department of Medicinal and Aromatic Plants, University of Health Sciences, 34668 Istanbul, Turkey. ${ }^{9}$ Faculty of Chemistry and Chemical Technology, Al-Farabi Kazakh National University, Almaty, Kazakhstan. ${ }^{10}$ Noncommunicable Diseases Research Center, Bam University of Medical Sciences, Bam, Iran. ${ }^{11}$ Student Research Committee, School of Medicine, Bam University of Medical Sciences, Bam, Iran. ${ }^{12}$ Department of Biotechnology, Graphic Era University, Dehradun, Uttarakhand 248001, India. ${ }^{13}$ Uttarakhand State Council for Science and Technology, Vigyan Dham, Dehradun, Uttarakhand 248007, India.

${ }^{14}$ Himalayan Environmental Studies and Conservation Organization, Prem Nagar, Dehradun, Uttarakhand 248001, India. ${ }^{15}$ Uttarakhand Council for Biotechnology, Silk Park, Prem Nagar, Dehradun, Uttarakhand 248007, India. ${ }^{16}$ CREA-Research Centre for Food and Nutrition, Via Ardeatina 546, 00178 Rome, Italy. ${ }^{17}$ Department of Nutrition and Dietetics, Faculty of Pharmacy, and Centre for Healthy Living, University of Concepción, 4070386 Concepción, Chile. ${ }^{18}$ Unidad de Desarrollo Tecnológico, UDT, Universidad de Concepción, 4070386 Concepción, Chile. ${ }^{19}$ Department of Chemistry, University of Alabama in Huntsville, Huntsville, AL 35899, USA. ${ }^{20}$ Aromatic Plant Research Center, 230 N 1200 E, Suite 100, Lehi, UT 84043, USA. ${ }^{21}$ Department of Botany, University of Fort Hare, Private Bag X1314, Alice 5700, South Africa. ${ }^{22}$ Zabol Medicinal Plants Research Center, Zabol University of Medical Sciences, Zabol, Iran.

\section{Received: 21 March 2020 Accepted: 24 July 2020} Published online: 01 August 2020

\section{References}

1. Matilla MA. Chapter 10 - metabolic responses of plants upon different plant-pathogen interactions. In: Ahmad P, Ahanger MA, Singh VP, Tripathi DK, Alam P, Alyemeni MN, editors. Plant metabolites and regulation under environmental stress. Cambridge: Academic Press; 2018. p. 195-214.

2. Imran M, Salehi B, Sharifi-Rad J, Gondal TA, Saeed F, Imran A, Shahbaz M, Fokou PVT, Arshad MU, Khan H, et al. Kaempferol: a key emphasis to its anticancer potential. Molecules. 2019;24(12):2277.

3. Sharifi-Rad J, Sharifi-Rad M, Salehi B, Iriti M, Roointan A, Mnayer D, SoltaniNejad A, Afshari A. In vitro and in vivo assessment of free radical scavenging and antioxidant activities of Veronica persica Poir. Cell Mol Biol. 2018;64(8):57-64.

4. Rauter AP, Ennis M, Hellwich K-H, Herold BJ, Horton D, Moss GP, Schomburg I. Nomenclature of flavonoids (IUPAC Recommendations 2017). Pure Appl Chem. 2018;90(9):1429.

5. Yao Y, Lin G, Xie Y, Ma P, Li G, Meng Q, Wu T. Preformulation studies of myricetin: a natural antioxidant flavonoid. Pharmazie. 2014;69(1):19-26.

6. Park K-S, Chong Y, Kim MK. Myricetin: biological activity related to human health. Appl Biol Chem. 2016;59(2):259-69.

7. Buchter C, Ackermann D, Havermann S, Honnen S, Chovolou Y, Fritz G, Kampkotter A, Watjen W. Myricetin-mediated lifespan extension in Caenorhabditis elegans is modulated by DAF-16. Int J Mol Sci. 2013;14(6): 11895-914.

8. Chobot V, Hadacek F. Exploration of pro-oxidant and antioxidant activities of the flavonoid myricetin. Redox Rep. 2011;16(6):242-7.

9. Sultana B, Anwar F. Flavonols (kaempeferol, quercetin, myricetin) contents of selected fruits, vegetables and medicinal plants. Food Chem. 2008;108(3): 879-84.

10. Jahan N, Khalil-Ur-Rahman AS, Asi MR. Phenolic acid and flavonol contents of gemmo-modified and native extracts of some indigenous medicinal plants. Pak J Bot. 2013:45(5):1515-9.

11. Mustafa RA, Abdul Hamid A, Mohamed S, Bakar FA. Total phenolic compounds, flavonoids, and radical scavenging activity of 21 selected tropical plants. J Food Sci. 2010;75(1):C28-35.

12. Hakkinen SH, Karenlampi SO, Heinonen IM, Mykkanen HM, Torronen AR. Content of the flavonols quercetin, myricetin, and kaempferol in 25 edible berries. J Agric Food Chem. 1999;47(6):2274-9.

13. Ozcan C, Yaman M. Determination of Myricetin in medicinal plants by highperformance liquid chromatography. Instrum Sci Technol. 2015;43(1):44-52.

14. Sarker U, Oba S. Antioxidant constituents of three selected red and green color Amaranthus leafy vegetable. Sci Rep. 2019;9(1):18233.

15. Nardini M, Garaguso I. Characterization of bioactive compounds and antioxidant activity of fruit beers. Food Chem. 2020;305:125437.
16. Mullie $P$, Clarys $P$, Deriemaeker $P$, Hebbelinck $M$. Estimation of daily human intake of food flavonoids. Plant Foods Hum Nutr. 2007;62(3):93-8.

17. Jun $\mathrm{S}$, Shin $\mathrm{S}$, Joung $\mathrm{H}$. Estimation of dietary flavonoid intake and major food sources of Korean adults. Br J Nutr. 2016;115(3):480-9.

18. Vogiatzoglou A, Mulligan AA, Lentjes MA, Luben RN, Spencer JP, Schroeter H, Khaw KT, Kuhnle GG. Flavonoid intake in European adults (18 to 64 years). PLoS One. 2015;10(5):e0128132.

19. Semwal D, Semwal R, Combrinck S, Viljoen A. Myricetin: a dietary molecule with diverse biological activities. Nutrients. 2016;8(2):90.

20. Yang Z-J, Wang H-R, Wang Y-I, Zhai Z-H, Wang L-W, Li L, Zhang C, Tang L. Myricetin attenuated diabetes-associated kidney injuries and dysfunction via regulating nuclear factor (erythroid derived 2)-like 2 and nuclear factor-kB signaling. Front Pharmacol. 2019;10:647.

21. Kim ME, Ha TK, Yoon JH, Lee JS. Myricetin induces cell death of human colon cancer cells via BAX/BCL2-dependent pathway. Anticancer Res. 2014; 34(2):701-6.

22. Kang BY, Kim SH, Cho D, Kim TS. Inhibition of interleukin-12 production in mouse macrophagesvia decreased nuclear factor-KB DNA binding activity by myricetin, a naturally occurring flavonoid. Arch Pharm Res. 2005;28(3): 274-9.

23. Giglio RV, Patti AM, Cicero AF, Lippi G, Rizzo M, Toth PP, Banach M. Polyphenols: potential use in the prevention and treatment of cardiovascular diseases. Curr Pharm Des. 2018;24(2):239-58.

24. Tong Y, Zhou X-M, Wang S-J, Yang Y, Cao Y-L. Analgesic activity of myricetin isolated from Myrica rubra Sieb. Et Zucc. Leaves. Arch Pharm Res. 2009;32(4):527-33.

25. Borde $\mathrm{P}$, Mohan M, Kasture S. Effect of myricetin on deoxycorticosterone acetate (DOCA)-salt-hypertensive rats. Nat Prod Res. 2011;25(16):1549-59.

26. De Leo M, Braca A, Sanogo R, Cardile V, DeTommasi N, Russo A. Antiproliferative activity of Pteleopsis suberosa leaf extract and its flavonoid components in human prostate carcinoma cells. Planta Med. 2006;72(7): 604-10.

27. Kong NN, Fang ST, Wang JH, Wang ZH, Xia CH. Two new flavonoid glycosides from the halophyte Limonium franchetii. J Asian Nat Prod Res. 2014;16(4):370-5.

28. Lau-Cam CA, Chan HH. Flavonoids from Comptonia peregrina. Phytochemistry. 1973;12(7):1829.

29. Jones JR, Lebar MD, Jinwal UK, Abisambra JF, Koren J 3rd, Blair L, O'Leary JC, Davey Z, Trotter J, Johnson AG, et al. The diarylheptanoid (+)-aR,11Smyricanol and two flavones from bayberry (Myrica cerifera) destabilize the microtubule-associated protein tau. J Nat Prod. 2011;74(1):38-44.

30. Abd El-Kader AM, El-Readi MZ, Ahmed AS, Nafady AM, Wink M, Ibraheim ZZ. Polyphenols from aerial parts of Polygonum bellardii and their biological activities. Pharm Biol. 2013:51(8):1026-34.

31. Kawasaki M, Kanomata T, Yoshitama K. Flavonoids in the leaves of twentyeight polygonaceous plants. Bot Mag. 1986;99(1):63-74.

32. Chua LS, Latiff NA, Lee SY, Lee CT, Sarmidi MR, Aziz RA. Flavonoids and phenolic acids from Labisia pumila (Kacip Fatimah). Food Chem. 2011; 127(3):1186-92

33. Ross JA, Kasum CM. Dietary flavonoids: bioavailability, metabolic effects, and safety. Annu Rev Nutr. 2002;22:19-34.

34. USDA: U.S. Department of Agriculture (USDA) Food database. Available: https://fdcnalusdagov/ 2020

35. Mikkonen TP, Maatta KR, Hukkanen AT, Kokko HI, Torronen AR, Karenlampi $\mathrm{SO}$, Karjalainen RO. Flavonol content varies among black currant cultivars. J Agric Food Chem. 2001;49(7):3274-7.

36. Martos I, Ferreres F, Yao L, D'Arcy B, Caffin N, Tomas-Barberan FA. Flavonoids in monospecific eucalyptus honeys from Australia. J Agric Food Chem. 2000:48(10):4744-8

37. Garrido J, Borges F. Wine and grape polyphenols - a chemical perspective. Food Res Int. 2013;54(2):1844-58.

38. Hsu YL, Liang HL, Hung CH, Kuo PL. Syringetin, a flavonoid derivative in grape and wine, induces human osteoblast differentiation through bone morphogenetic protein-2/extracellular signal-regulated kinase 1/2 pathway. Mol Nutr Food Res. 2009;53(11):1452-61.

39. Górniak I, Bartoszewski R, Króliczewski J. Comprehensive review of antimicrobial activities of plant flavonoids. Phytochem Rev. 2019;18(1):241-72.

40. Salehi B, Sharopov F, Martorell M, Rajkovic J, Ademiluyi AO, Sharifi-Rad M, Fokou PVT, Martins N, Iriti M, Sharifi-Rad J. Phytochemicals in Helicobacter pylori infections: What are we doing now? Int J Mol Sci. 2018;19(8):2361. 
41. Wu T, Zang X, He M, Pan S, Xu X. Structure-activity relationship of flavonoids on their anti-Escherichia coli activity and inhibition of DNA gyrase. J Agric Food Chem. 2013;61(34):8185-90.

42. Griep MA, Blood S, Larson MA, Koepsell SA, Hinrichs SH. Myricetin inhibits Escherichia coli DnaB helicase but not primase. Bioorg Med Chem. 2007; 15(22):7203-8

43. Ono K, Nakane H, Fukushima M, Chermann JC, Barre-Sinoussi F. Differential inhibitory effects of various flavonoids on the activities of reverse transcriptase and cellular DNA and RNA polymerases. Eur J Biochem. 1990; 190(3):469-76.

44. Cetin-Karaca H, Newman MC. Antimicrobial efficacy of plant phenolic compounds against Salmonella and Escherichia Coli. Food Biosci. 2015;11:8-16.

45. Arita-Morioka K-I, Yamanaka K, Mizunoe Y, Ogura T, Sugimoto S. Novel strategy for biofilm inhibition by using small molecules targeting molecular chaperone DnaK. Antimicrob Agents Chemother. 2015:59(1):633-41.

46. Pasetto S, Pardi V, Murata RM. Anti-HIV-1 activity of flavonoid myricetin on HIV-1 infection in a dual-chamber in vitro model. PLoS One. 2014;9(12): e115323.

47. Yadav AK, Thakur J, Prakash O, Khan F, Saikia D, Gupta MM. Screening of flavonoids for antitubercular activity and their structure-activity relationships. Med Chem Res. 2013;22(6):2706-16.

48. Yu M-S, Lee J, Lee JM, Kim Y, Chin Y-W, Jee J-G, Keum Y-S, Jeong Y-J. Identification of myricetin and scutellarein as novel chemical inhibitors of the SARS coronavirus helicase, nsP13. Bioorg Med Chem Lett. 2012;22(12): 4049-54.

49. DeSouza $L$, Wahidullah S. Antibacterial phenolics from the mangrove Lumnitzera racemosa; 2010.

50. Gendaram O, Choi YH, Kim YS, Ryu SY. Anti-oxidative and antibacterial constituents from Sedum hybridum. Nat Prod Sci. 2011;17:279-84.

51. Nitulescu G, Nicorescu IM, Olaru OT, Ungurianu A, Mihai DP, Zanfirescu A, Nitulescu GM, Margina D. Molecular docking and screening studies of new natural Sortase a inhibitors. Int J Mol Sci. 2017;18(10):2217.

52. Jayaraman P, Sakharkar MK, Lim CS, Tang TH, Sakharkar KR. Activity and interactions of antibiotic and phytochemical combinations against Pseudomonas aeruginosa in vitro. Int J Biol Sci. 2010;6(6):556.

53. Chu S-C, Hsieh Y-S, Lin J-Y. Inhibitory effects of flavonoids on Moloney murine leukemia virus reverse transcriptase activity. J Nat Prod. 1992;55(2): 179-83.

54. Cai L, Wu CD. Compounds from Syzygium aromaticum possessing growth inhibitory activity against oral pathogens. J Nat Prod. 1996:59(10):987-90.

55. Xu HX, Lee SF. Activity of plant flavonoids against antibiotic-resistant bacteria. Phytother Res. 2001;15(1):39-43.

56. Naz S, Siddiqi R, Ahmad S, Rasool S, Sayeed S. Antibacterial activity directed isolation of compounds from Punica granatum. J Food Sci. 2007:72(9): M341-5.

57. Kang SS, Kim J-G, Lee T-H, Oh K-B. Flavonols inhibit sortases and sortasemediated Staphylococcus aureus clumping to fibrinogen. Biol Pharm Bull. 2006;29(8):1751-5.

58. Demetzos C, Angelopoulou D, Kolocouris A, Daliani I, Mavromoustakos T. Structure elucidation, conformational analysis and thermal effects on membrane bilayers of an antimicrobial myricetin ether derivative. J Heterocyclic Chem. 2001;38(3):703-10.

59. Lin RD, Chin YP, Lee MH. Antimicrobial activity of antibiotics in combination with natural flavonoids against clinical extended-spectrum $\beta$-lactamase (ESBL)-producing Klebsiella pneumoniae. Phytother Res. 2005;19(7):612-7.

60. Alvesalo J, Vuorela H, Tammela P, Leinonen M, Saikku P, Vuorela P. Inhibitory effect of dietary phenolic compounds on chlamydia pneumoniae in cell cultures. Biochem Pharmacol. 2006;71(6):735-41.

61. Hou Y, Zhang F, Lan J, Sun F, Li J, Li M, Song K, Wu X. Ultra-small micelles based on polyoxyl 15 hydroxystearate for ocular delivery of myricetin: optimization, in vitro, and in vivo evaluation. Drug delivery. 2019;26(1):158-67.

62. Barzegar A. Antioxidant activity of polyphenolic myricetin in vitro cell-free and cell-based systems. Mole Biol Res Commun. 2016;5(2):87.

63. Guitard R, Paul J-F, Nardello-Rataj V, Aubry J-M. Myricetin, rosmarinic and carnosic acids as superior natural antioxidant alternatives to a-tocopherol for the preservation of omega-3 oils. Food Chem. 2016;213:284-95.

64. Sadasivam K, Kumaresan R. Antioxidant behavior of mearnsetin and myricetin flavonoid compounds-a DFT study. Spectrochim Acta A Mol Biomol Spectrosc. 2011;79(1):282-93.
65. Qin S, Chen J, Tanigawa S, Hou DX. Microarray and pathway analysis highlight Nrf2/ARE-mediated expression profiling by polyphenolic myricetin. Mol Nutr Food Res. 2013;57(3):435-46.

66. Yao Y, Xie Y, Hong C, Li G, Shen H, Ji G. Development of a myricetin/ hydroxypropyl- $\beta$-cyclodextrin inclusion complex: preparation, characterization, and evaluation. Carbohydr Polym. 2014;110:329-37.

67. Mahjoub MA, Ammar S, Edziri H, Mighri N, Bouraoui A, Mighri Z. Antiinflammatory and antioxidant activities of some extracts and pure natural products isolated from Rhus tripartitum (Ucria). Med Chem Res. 2010;19(3): 271-82.

68. Pandey KB, Rizvi SI. Ferric reducing and radical scavenging activities of selected important polyphenols present in foods. Int J Food Prop. 2012; 15(3):702-8

69. Tuberoso CIG, Boban M, Bifulco E, Budimir D, Pirisi FM. Antioxidant capacity and vasodilatory properties of Mediterranean food: the case of Cannonau wine, myrtle berries liqueur and strawberry-tree honey. Food Chem. 2013; 140(4):686-91.

70. Fu Y, Qiao L, Cao Y, Zhou X, Liu Y, Ye X. Structural elucidation and antioxidant activities of proanthocyanidins from Chinese bayberry (Myrica rubra Sieb. et Zucc.) leaves. PLoS One. 2014;9(5):e96162.

71. Chaabi M, Beghidja N, Benayache S, Lobstein A. Activity-guided isolation of antioxidant principles from Limoniastrum feei (Girard) batt. Z Naturforsch C J Biosci. 2008;63(11-12):801-7.

72. Mendes V, Vilaça R, de Freitas V, Ferreira PM, Mateus N, Costa V. Effect of myricetin, pyrogallol, and phloroglucinol on yeast resistance to oxidative stress. Oxidative Med Cell Longev. 2015;2015:782504.

73. Wang ZH, Kang KA, Zhang R, Piao MJ, Jo SH, Kim JS, Kang SS, Lee JS, Park $\mathrm{DH}$, Hyun JW. Myricetin suppresses oxidative stress-induced cell damage via both direct and indirect antioxidant action. Environ Toxicol Pharmacol. 2010;29(1):12-8.

74. Sueishi Y, Hori M. Nitric oxide scavenging rates of solubilized resveratrol and flavonoids. Nitric Oxide. 2013;29:25-9.

75. Chen W, Li Y, Li J, Han Q, Ye L, Li A. Myricetin affords protection against peroxynitrite-mediated DNA damage and hydroxyl radical formation. Food Chem Toxicol. 2011;49(9):2439-44.

76. Zhang D, Xie L, Jia G, Cai S, Ji B, Liu Y, Wu W, Zhou F, Wang A, Chu L. Comparative study on antioxidant capacity of flavonoids and their inhibitory effects on oleic acid-induced hepatic steatosis in vitro. Eur J Med Chem. 2011:46(9):4548-58.

77. Kang KA, Wang ZH, Zhang R, Piao MJ, Kim KC, Kang SS, Kim YW, Lee J, Park $D$, Hyun JW. Myricetin protects cells against oxidative stress-induced apoptosis via regulation of PI3K/Akt and MAPK signaling pathways. Int J Mol Sci. 2010;11(11):4348-60.

78. Henneberg R, Otuki MF, Furman AEF, Hermann P, Nascimento AJD, Leonart MSS. Protective effect of flavonoids against reactive oxygen species production in sickle cell anemia patients treated with hydroxyurea. Rev Bras Hematol Hemoter. 2013;35(1):52-5.

79. Vauzour D, Vafeiadou K, Rodriguez-Mateos A, Rendeiro C, Spencer JP. The neuroprotective potential of flavonoids: a multiplicity of effects. Genes Nutr. 2008;3(3):115

80. Mohan M, Jadhav SS, Kasture VS, Kasture SB. Effect of myricetin on behavioral paradigms of anxiety. Pharm Biol. 2009;47(10):927-31.

81. Fiori J, Naldi M, Bartolini M, Andrisano V. Disclosure of a fundamental clue for the elucidation of the myricetin mechanism of action as amyloid aggregation inhibitor by mass spectrometry. Electrophoresis. 2012;33(22): 3380-6.

82. Naldi M, Fiori J, Pistolozzi M, Drake AF, Bertucci C, Wu R, Mlynarczyk K, Filipek S, De Simone A, Andrisano V. Amyloid beta-peptide 25-35 selfassembly and its inhibition: a model undecapeptide system to gain atomistic and secondary structure details of the Alzheimer's disease process and treatment. ACS Chem Neurosci. 2012;3(11):952-62.

83. DeToma AS, Choi JS, Braymer JJ, Lim MH. Myricetin: a naturally occurring regulator of metal-induced amyloid- $\beta$ aggregation and neurotoxicity. ChemBioChem. 2011;12(8):1198-201.

84. Shimmyo $Y$, Kihara T, Akaike A, Niidome T, Sugimoto $H$. Multifunction of myricetin on $A \beta$ : neuroprotection via a conformational change of $A \beta$ and reduction of $A \beta$ via the interference of secretases. J Neurosci Res. 2008; 86(2):368-77.

85. Ono K, Yamada M. Antioxidant compounds have potent anti-fibrillogenic and fibril-destabilizing effects for a-synuclein fibrils in vitro. J Neurochem. 2006;97(1):105-15 
86. Ono K, Yoshiike Y, Takashima A, Hasegawa K, Naiki H, Yamada M. Potent anti-amyloidogenic and fibril-destabilizing effects of polyphenols in vitro: implications for the prevention and therapeutics of Alzheimer's disease. J Neurochem. 2003;87(1):172-81.

87. Ramezani M, Darbandi N, Khodagholi F, Hashemi A. Myricetin protects hippocampal CA3 pyramidal neurons and improves learning and memory impairments in rats with Alzheimer's disease. Neural Regen Res. 2016;11(12): 1976.

88. Joshi V, Mishra R, Upadhyay A, Amanullah A, Poluri KM, Singh S, Kumar A, Mishra A. Polyphenolic flavonoid (Myricetin) upregulated proteasomal degradation mechanisms: eliminates neurodegenerative proteins aggregation. J Cell Physiol. 2019;234:20900-14.

89. Zhang XH, Ma ZG, Rowlands DK, Gou YL, Fok KL, Wong HY, Yu MK, Tsang $\mathrm{LL}, \mathrm{Mu} \mathrm{L}$, Chen $\mathrm{L}$. Flavonoid myricetin modulates receptor activity through activation of channels and CaMK-II pathway. Evid Based Complement Alternat Med. 2012;2012:758097.

90. Ren Z, Yan P, Zhu L, Yang H, Zhao Y, Kirby BP, Waddington JL, Zhen X. Dihydromyricetin exerts a rapid antidepressant-like effect in association with enhancement of BDNF expression and inhibition of neuroinflammation. Psychopharmacology. 2018;235(1):233-44.

91. Ma Z, Wang G, Cui L, Wang Q. Myricetin attenuates depressant-like behavior in mice subjected to repeated restraint stress. Int J Mol Sci. 2015;16(12): 28377-85.

92. Lei Y, Chen J, Zhang W, Fu W, Wu G, Wei H, Wang Q, Ruan J. In vivo investigation on the potential of galangin, kaempferol and myricetin for protection of D-galactose-induced cognitive impairment. Food Chem. 2012; 135(4):2702-7.

93. Sun ZQ, Meng FH, Tu LX, Sun L. Myricetin attenuates the severity of seizures and neuroapoptosis in pentylenetetrazole kindled mice by regulating the of BDNF-TrkB signaling pathway and modulating matrix metalloproteinase-9 and GABAA. Exp Ther Med. 2019;17(4):3083-91.

94. Khan E, Tawani A, Mishra SK, Verma AK, Upadhyay A, Kumar M, Sandhir R, Mishra A, Kumar A. Myricetin reduces toxic level of CAG repeats RNA in Huntington's disease (HD) and Spino cerebellar Ataxia (SCAs). ACS Chem Biol. 2017;13(1):180-8.

95. Zhang K, Ma Z, Wang J, Xie A, Xie J. Myricetin attenuated MPP+-induced cytotoxicity by anti-oxidation and inhibition of MKK4 and JNK activation in MES23. 5 cells. Neuropharmacol. 2011;61(1-2):329-35.

96. Huang B, Liu J, Ma D, Chen G, Wang W, Fu S. Myricetin prevents dopaminergic neurons from undergoing neuroinflammation-mediated degeneration in a lipopolysaccharide-induced Parkinson's disease model. J Funct Foods. 2018;45:452-61.

97. Ara G, Afzal M, Jyoti S, Siddique YH. Effect of myricetin on the transgenic Drosophila model of Parkinson's disease. Bull Fac Pharm Cairo Univ. 2017; 55(2):259-62.

98. Ara G, Afzal M, Jyoti S, Naz F, Siddique YH. Effect of Myricetin on the loss of dopaminergic neurons in the transgenic Drosophila model of Parkinson's disease. Curr Drug Therapy. 2019;14(1):58-64.

99. Caruana M, Högen T, Levin J, Hillmer A, Giese A, Vassallo N. Inhibition and disaggregation of a-synuclein oligomers by natural polyphenolic compounds. FEBS Lett. 2011;585(8):1113-20.

100. Ma Z-G, Wang J, Jiang H, Liu T-W, Xie J-X. Myricetin reduces 6hydroxydopamine-induced dopamine neuron degeneration in rats. Neuroreport. 2007;18(11):1181-5.

101. Karunakaran U, Elumalai S, Moon JS, Jeon J-H, Kim ND, Park K-G, Won KC, Leem J, Lee I-K. Myricetin protects against high glucose-induced $\beta$-cell apoptosis by attenuating endoplasmic reticulum stress via inactivation of cyclin-dependent kinase 5. Diabetes Metab J. 2019;43(2):192-205.

102. Li Y, Zheng X, Yi X, Liu C, Kong D, Zhang J, Gong M. Myricetin: a potent approach for the treatment of type 2 diabetes as a natural class B GPCR agonist. FASEB J. 2017;31(6):2603-11.

103. Saltiel AR, Kahn CR. Insulin signalling and the regulation of glucose and lipid metabolism. Nature. 2001;414(6865):799-806.

104. Kraegen EW, Bruce C, Hegarty BD, Ye JM, Turner N, Cooney G. AMPactivated protein kinase and muscle insulin resistance. Front Biosci (Landmark ed). 2009;14:4658-72.

105. Ding Y, X-q D, Z-f Z, Li Y. Myricetin attenuates hyperinsulinemia-induced insulin resistance in skeletal muscle cells. Eur Food Res Technol. 2012;234(5): 873-81.
106. Tzeng T-F, Liou S-S, Liu I-M. Myricetin ameliorates defective post-receptor insulin signaling via $\beta$-endorphin signaling in the skeletal muscles of fructose-fed rats. Evid Based Complement Alternat Med. 2011;2011:150752.

107. Li Y, Ding Y. Minireview: therapeutic potential of myricetin in diabetes mellitus. Food Sci Human Wellness. 2012;1(1):19-25.

108. Tzeng TF, Liou SS, Liu IM. Myricetin ameliorates defective post-receptor insulin signaling via beta-endorphin signaling in the skeletal muscles of fructose-fed rats. Evid Based Complement Alternat Med. 2011;2011:150752.

109. Kandasamy N, Ashokkumar N. Myricetin modulates streptozotocincadmium induced oxidative stress in long term experimental diabetic nephrotoxic rats. J Funct Foods. 2013;5(3):1466-77.

110. Kang S-J, Park J-HY, Choi H-N, Kim J-I. a-Glucosidase inhibitory activities of myricetin in animal models of diabetes mellitus. Food Sci Biotechnol. 2015; 24(5):1897-900.

111. Kandasamy N, Ashokkumar N. Myricetin, a natural flavonoid, normalizes hyperglycemia in streptozotocin-cadmium-induced experimental diabetic nephrotoxic rats. Biomed Prev Nutr. 2012;2(4):246-51.

112. Ozcan F, Ozmen A, Akkaya B, Aliciguzel Y, Aslan M. Beneficial effect of myricetin on renal functions in streptozotocin-induced diabetes. Clin Exp Med. 2012;12(4):265-72.

113. Pandey KB, Mishra N, Rizvi SI. Myricetin may provide protection against oxidative stress in type 2 diabetic erythrocytes. Z Naturforsch C. 2009;64(910):626-30.

114. Ong KC, Khoo H-E. Effects of myricetin on glycemia and glycogen metabolism in diabetic rats. Life Sci. 2000;67(14):1695-705.

115. Ong KC, Khoo H-E. Insulinomimetic effects of myricetin on lipogenesis and glucose transport in rat adipocytes but not glucose transporter translocation. Biochem Pharmacol. 1996;51(4):423-9.

116. Tadera K, Minami Y, Takamatsu K, Matsuoka T. Inhibition of a-glucosidase and a-amylase by flavonoids. J Nutr Sci Vitaminol. 2006;52(2):149-53.

117. Liu I-M, Tzeng T-F, Liou S-S, Lan T-W. Improvement of insulin sensitivity in obese Zucker rats by myricetin extracted from Abelmoschus moschatus. Planta Med. 2007;73(10):1054-60.

118. Chen J, Wu Y, Zou J, Gao K. a-Glucosidase inhibition and antihyperglycemic activity of flavonoids from Ampelopsis grossedentata and the flavonoid derivatives. Bioorg Med Chem. 2016;24(7):1488-94.

119. Satyanarayana K, Sravanthi K, Shaker IA, Ponnulakshmi R. Molecular approach to identify antidiabetic potential of Azadirachta indica. J Ayurveda Integr Med. 2015;6(3):165.

120. Meng Y, Su A, Yuan S, Zhao H, Tan S, Hu C, Deng H, Guo Y. Evaluation of total flavonoids, myricetin, and quercetin from Hovenia dulcis Thunb. As inhibitors of a-amylase and a-glucosidase. Plant Foods Hum Nutr. 2016; 71(4):444-9.

121. Benkhayal FA, Musbah E-G, Ramesh S, Dhayabaran D. Biochemical studies on the effect of phenolic compounds extracted from Myrtus communis in diabetic rats. Tamilnadu J Vet Animal Sci. 2009;5:87-93.

122. Syama HP, Arun KB, Sinumol G, Dhanya R, Suseela Anusree S, Nisha P, Ravi Shankar L, Sundaresan A, Jayamurthy P. Syzygium cumini seed exhibits antidiabetic potential via multiple pathways involving inhibition of aglucosidase, DPP-IV, glycation, and ameliorating glucose uptake in L6 cell lines. J Food Process Preserv. 2018;42(2):e13464.

123. Arumugam B, Palanisamy UD, Chua KH, Kuppusamy UR. Potential antihyperglycaemic effect of myricetin derivatives from Syzygium malaccense. J Funct Foods. 2016;22:325-36.

124. Haick H, Broza YY, Mochalski P, Ruzsanyi V, Amann A. Assessment, origin, and implementation of breath volatile cancer markers. Chem Soc Rev. 2014; 43(5):1423-49.

125. MohanáAgarwal S. VOCC: a database of volatile organic compounds in cancer. RSC Adv. 2016:6(115):114783-9.

126. White MC, Holman DM, Boehm JE, Peipins LA, Grossman M, Henley SJ. Age and cancer risk: a potentially modifiable relationship. Am J Prev Med. 2014; 46(3):S7-S15.

127. Mishra AP, Salehi B, Sharifi-Rad M, Pezzani R, Kobarfard F, Sharifi-Rad J, Nigam M. Programmed cell death, from a Cancer perspective: an overview. Mole Diagn Ther. 2018;22(3):281-95.

128. Ma L, Cao X, Wang H, Lu K, Wang Y, Tu C, Dai Y, Meng Y, Li Y, Yu P. Discovery of Myricetin as a potent inhibitor of human flap endonuclease 1 , which potentially can be used as sensitizing agent against HT-29 human Colon Cancer cells. J Agric Food Chem. 2019;67(6):1656-65. 
129. Huang H, Chen AY, Ye X, Li B, Rojanasakul Y, Rankin GO, Chen YC. Myricetin inhibits proliferation of cisplatin-resistant cancer cells through a p53dependent apoptotic pathway. Int J Oncol. 2015;47(4):1494-502.

130. Xu Y, Xie Q, Wu S, Yi D, Yu Y, Liu S, Li S, Li Z. Myricetin induces apoptosis via endoplasmic reticulum stress and DNA double-strand breaks in human ovarian cancer cells. Mol Med Rep. 2016;13(3):2094-100.

131. Zheng AW, Chen YQ, Zhao LQ, Feng JG. Myricetin induces apoptosis and enhances chemosensitivity in ovarian cancer cells. Oncol Lett. 2017;13(6): 4974-8

132. Tavsan Z, Kayali HA. Flavonoids showed anticancer effects on the ovarian cancer cells: involvement of reactive oxygen species, apoptosis, cell cycle and invasion. Biomed Pharmacother. 2019;116:109004.

133. Lee KW, Kang NJ, Rogozin EA, Kim H-G, Cho YY, Bode AM, Lee HJ, Surh Y-J, Bowden GT, Dong Z. Myricetin is a novel natural inhibitor of neoplastic cell transformation and MEK1. Carcinogenesis. 2007;28(9):1918-27.

134. Kang NJ, Jung SK, Lee KW, Lee HJ. Myricetin is a potent chemopreventive phytochemical in skin carcinogenesis. Ann N Y Acad Sci. 2011;1229(1):124-32

135. Sun W, Tao Y, Yu D, Zhao T, Wu L, Yu W, Han W. Myricetin exerts potent anticancer effects on human skin tumor cells. Trop J Pharm Res. 2018;17(6): 1067-72.

136. Shih Y-W, Wu P-F, Lee Y-C, Shi M-D, Chiang T-A. Myricetin suppresses invasion and migration of human lung adenocarcinoma A549 cells: possible mediation by blocking the ERK signaling pathway. J Agric Food Chem. 2009;57(9):3490-9.

137. Zhang S, Wang L, Liu H, Zhao G, Ming L. Enhancement of recombinant myricetin on the radiosensitivity of lung cancer A549 and H1299 cells. Diagn Pathol. 2014;9(1):68.

138. Wang L, Feng J, Chen X, Guo W, Du Y, Wang Y, Zang W, Zhang S, Zhao G. Myricetin enhance chemosensitivity of 5-fluorouracil on esophageal carcinoma in vitro and in vivo. Cancer Cell Int. 2014;14(1):71.

139. Sun F, Zheng XY, Ye J, Wu TT, Wang JL, Chen W. Potential anticancer activity of myricetin in human T24 bladder cancer cells both in vitro and in vivo. Nutr Cancer. 2012;64(4):599-606.

140. Ghassemi-Rad J, Maleki M, Knickle AF, Hoskin DW. Myricetin-induced oxidative stress suppresses murine T lymphocyte activation. Cell Biol Int. 2018;42(8):1069-75.

141. Jiménez R, Andriambeloson E, Duarte J, Andriantsitohaina R, Jiménez J, Pérez-Vizcaino F, Zarzuelo A, Tamargo J. Involvement of thromboxane A2 in the endothelium-dependent contractions induced by myricetin in rat isolated aorta. Br J Pharmacol. 1999;127(7):1539-44.

142. Cho Y-C, Yoon G, Lee KY, Choi HJ, Kang BY. Inhibition of interleukin-2 production by myricetin in mouse EL-4 T cells. Arch Pharm Res. 2007;30(9): 1075-9.

143. Lee SE, Park YS. Gene expression profiling of human umbilical vein endothelial cells exposed to myricetin. BioChip J. 2013;7(4):335-43.

144. Lian T-W, Wang L, Lo Y-H, Huang I-J, Wu M-J. Fisetin, morin and myricetin attenuate CD36 expression and oxLDL uptake in U937-derived macrophages. Biochim Biophys Acta. 2008;1781(10):601-9.

145. Angelone T, Pasqua T, Di Majo D, Quintieri A, Filice E, Amodio N, Tota B, Giammanco M, Cerra M. Distinct signalling mechanisms are involved in the dissimilar myocardial and coronary effects elicited by quercetin and myricetin, two red wine flavonols. Nutr Metab Cardiovasc Dis. 2011;21(5): 362-71.

146. Bhatia G, Khanna A, Sonkar R, Mishra S, Srivastava S, Lakshmi V. Lipid lowering and antioxidant activity of flavones in triton treated hyperlipidemic rats. Med Chem Res. 2011;20(9):1622-6.

147. Tiwari R, Mohan M, Kasture S, Maxia A, Ballero M. Cardioprotective potential of myricetin in isoproterenol-induced myocardial infarction in Wistar rats. Phytother Res. 2009:23(10):1361-6.

148. Scarabelli TM, Mariotto S, Abdel-Azeim S, Shoji K, Darra E, Stephanou A, Chen-Scarabelli C, Marechal JD, Knight R, Ciampa A. Targeting STAT1 by myricetin and delphinidin provides efficient protection of the heart from ischemia/reperfusion-induced injury. FEBS Lett. 2009;583(3):531-41.

149. Hagenacker T, Hillebrand I, Wissmann A, Büsselberg D, Schäfers M. Antiallodynic effect of the flavonoid myricetin in a rat model of neuropathic pain: involvement of p38 and protein kinase $\mathrm{C}$ mediated modulation of Ca2+ channels. Eur J Pain. 2010;14(10):992-8.

150. Godse S, Mohan M, Kasture V, Kasture S. Effect of myricetin on blood pressure and metabolic alterations in fructose hypertensive rats. Pharm Biol. 2010;48(5):494-8.
151. Moghadam S, Ebrahimi S, Salehi P, Moridi Farimani M, Hamburger M, Jabbarzadeh E. Wound healing potential of chlorogenic acid and Myricetin3-O- $\beta$-Rhamnoside isolated from Parrotia persica. Molecules. 2017;22(9):1501.

152. Sun J, Sun J, Zhou X. Protective functions of myricetin in LPS-induced cardiomyocytes H9c2 cells injury by regulation of MALAT1. Eur J Med Res. 2019;24(1):20

153. Zhu S, Yang C, Zhang L, Wang S, Ma M, Zhao J, Song Z, Wang F, Qu X, Li F, et al. Development of M10, myricetin-3-O-beta-d-lactose sodium salt, a derivative of myricetin as a potent agent of anti-chronic colonic inflammation. Eur J Med Chem. 2019;174:9-15.

154. Abidov M, Ramazanov A, Jimenez Del Rio M, Chkhikvishvili I. Effect of Blueberin on fasting glucose, C-reactive protein and plasma aminotransferases, in female volunteers with diabetes type 2: double-blind, placebo controlled clinical study. Georgian Med News. 2006;141:66-72.

155. Ahrens MJ, Thompson DL. Effect of emulin on blood glucose in type 2 diabetics. J Med Food. 2013;16(3):211-5.

156. Devi KP, Rajavel T, Habtemariam S, Nabavi SF, Nabavi SM. Molecular mechanisms underlying anticancer effects of myricetin. Life Sci. 2015;142: $19-25$.

157. Knekt P, Kumpulainen J, Jarvinen R, Rissanen $H$, Heliovaara M, Reunanen A, Hakulinen T, Aromaa A. Flavonoid intake and risk of chronic diseases. Am J Clin Nutr. 2002;76(3):560-8.

158. Gates MA, Tworoger SS, Hecht JL, De Vivo I, Rosner B, Hankinson SE. A prospective study of dietary flavonoid intake and incidence of epithelial ovarian cancer. Int J Cancer. 2007;121(10):2225-32.

159. Bobe G, Weinstein SJ, Albanes D, Hirvonen T, Ashby J, Taylor PR, Virtamo J, Stolzenberg-Solomon RZ. Flavonoid intake and risk of pancreatic cancer in male smokers (Finland). Cancer Epidemiol Biomark Prev. 2008;17(3):553-62

160. Tang NP, Zhou B, Wang B, Yu RB, Ma J. Flavonoids intake and risk of lung cancer: a meta-analysis. Jpn J Clin Oncol. 2009;39(6):352-9.

161. Zern TL, Wood RJ, Greene C, West KL, Liu Y, Aggarwal D, Shachter NS, Fernandez ML. Grape polyphenols exert a cardioprotective effect in preand postmenopausal women by lowering plasma lipids and reducing oxidative stress. J Nutr. 2005;135(8):1911-7.

\section{Publisher's Note}

Springer Nature remains neutral with regard to jurisdictional claims in published maps and institutional affiliations.
Ready to submit your research? Choose BMC and benefit from:

- fast, convenient online submission

- thorough peer review by experienced researchers in your field

- rapid publication on acceptance

- support for research data, including large and complex data types

- gold Open Access which fosters wider collaboration and increased citations

- maximum visibility for your research: over $100 \mathrm{M}$ website views per year

At BMC, research is always in progress.

Learn more biomedcentral.com/submissions 